\title{
Shallow groundwater chemical evolution, isotopic hyperfiltration, and salt pan formation in a hypersaline endorheic basin: Pilot Valley, Great Basin, USA
}

\author{
A. L. Mayo ${ }^{1,2}$ (1) $\cdot$ D. G. Tingey ${ }^{1}$ \\ Received: 30 December 2020 / Accepted: 26 May 2021 / Published online: 21 June 2021 \\ (C) The Author(s) 2021
}

\begin{abstract}
Endorheic basin brines are of economic significance as sources of boron, iodine, magnesium, potassium, sodium sulfate, sodium carbonate, and tungsten, and they are a major source of the critical metal lithium. Although evaporation is the primary hypersalinization driver for evaporative water bodies, recent investigations have proposed more novel mechanisms for some subsurface brine. This investigation explores shallow groundwater hypersalinization. The chemical evolution and isotopic fractionation of shallow hypersaline groundwater in the clay-rich arid endorheic basin sediments of Pilot Valley, Great Basin (USA), were investigated. Groundwater evolves from fresh in the mountain bedrock and alluvial fans, to brackish and saline at the alluvial fan-playa interface, and to hypersaline in the upper $12 \mathrm{~m}$ of basin sediments. Alluvial fan systems are isolated from each other and have varying groundwater ${ }^{3} \mathrm{H}$ and ${ }^{14} \mathrm{C}$ travel times. Nonevaporative in-situ isotopic fractionation of up to $-8 \%$ in $\delta^{18} \mathrm{O}$ is attributed to clay sequence hyperfiltration. Groundwater flow-path sulfate and chloride mineral dissolution is the primary driving mechanism for both interface and basin groundwater evolution. Evaporation only impacts the groundwater quality in a small portion of the basin where the groundwater is within $\sim 1 \mathrm{~m}$ of the ground surface. Here capillary action carries dissolved soluble salts to the land surface. Episodic flooding redissolves and carries the precipitated salt to the annually flooded salt pan where it accumulates as a salt crust during the dry season. The Pilot Valley model may help explain the buildup accumulative layers of soluble salt that when remobilized becomes subsurface brine.
\end{abstract}

Keywords Hyperfiltration · Isotopic fractionation $\cdot$ Geochemical evolution $\cdot$ Fresh-salt water relations $\cdot$ USA

\section{Introduction}

Approximately $20 \%$ of the Earth's land surface is covered by endorheic basins, but the basins only account for $2.3 \%$ of the total worldwide annual river runoff (UNESCO 2014). The basins typically occur in arid and semiarid regions where the worldwide average precipitation is $54.1 \mathrm{~mm}^{-1} \mathrm{ear}^{-1}$ compared to the average for exoreic regions of $321.5 \mathrm{~mm}$ year $^{-1}$ (Meybeck et al. 2001). Although endorheic basins are ubiquitous, the evolution of their groundwater geochemistry,

\footnotetext{
A. L. Mayo

alan_mayo@live.com

D. G. Tingey

dgtingey@gmail.com

1 Brigham Young University, Provo, UT, USA

2 Mayo and Associates LC, Phoenix, AR, USA
}

particularly high saline waters, has not received the same level of attention as has other aspects of hydrogeology. Coastal and hydrogeological processes that involve anthropogenic and paleo-groundwater influences have been found to be a factor in the evolution of some high salinity groundwaters (Lowenstein and Risacher 2009; Post et al. 2014; Sabarathinam et al. 2018; Van Engelen et al. 2017). Salinization may also be the result of diffuse recharge of residual water associated with transpiration and evaporation (Cartwright et al. 2007), the dissolution and mobilization of evaporite soil-zone and aquifer minerals (Massuel et al. 2006; Mayo et al. 2010; Scanlon et al. 2009), biogenic processes (Mayo et al. 2007), and discharge zone evaporation (Shuya et al. 2018; Tweed et al. 2011). In recent years portions of the Great Australian Basin have been reevaluated by geochemical means (Love et al. 2017; Priestley et al. 2017: Shand et al. 2013) as has the geochemical evolution of a few endorheic basins in China, Central and South America, and Turkey (Bayari et al. 2008; Edmonds et al. 2006; He et al. 2015; 
Herrera et al. 2016; Johnson et al. 2010; Ortega 2003; Xiao et al. 2017, 2018).

Endorheic basin brines are of great economic significance as sources of boron, iodine, lithium, magnesium, potassium, sodium sulfate, sodium carbonate, and tungsten (Hardie 1991; Eugster 1980; Riascher and Fritz 2009; Rosen 1994)-for example, one-third of the world's lithium is from a single source, the Salar de Atacama in Chile, and the Salar de Uyuni in Boliva may contain the world largest lithium reserves. Traditionally mineral leaching coupled with evaporation has been considered to be the primary driver of basin hypersalinization; however, recent investigations have cast a wider net. Duffy and Al-Hassen (1998) and Hamann et al. (2015) have modeled coupled evaporation-convective groundwater flow as a salinization mechanism. Marazuela et al. (2020) found that thermohaline flow associated with fault damage zones promote the remobilization of lithium in the Salar de Atacama. Rissman et al. (2015) proposed that brine leakage from active salars (salt flats) coupled with groundwater flow in the high Andes of the Atacama Desert concentrates brines in the Salar de Atacama. Of interest here is the development of a better understanding of the hypersalinization processes in shallow, active zone endorheic basin groundwater. Pilot Valley, located in the Western United States Great Basin (Fig. 1), was selected for study because it is a readily accessible, has not been significantly impacted by anthropogenic processes, is partially covered by a salt pan, is of a manageable size for in-depth research, and has shallow groundwater chemistry that evolves from fresh to hypersaline along sort flow paths. Pilot Valley was a western embayment of the vast Pleistocene age pluvial Lake Bonneville.

\section{Previous Pilot Valley investigations}

Early Pilot Valley investigations focused on Lake Bonneville history and the origin of the salt crust (Gilbert 1890; Nolan 1928; Stansbury 1852). The near surface geology of the valley has been well documented (Anderson 1957, 1960; Miller
Fig. 1 Google Earth image of Pilot Valley and the bounding Pilot and Silver Island Ranges. In this article, the Playa outline is used in figures without location attribution

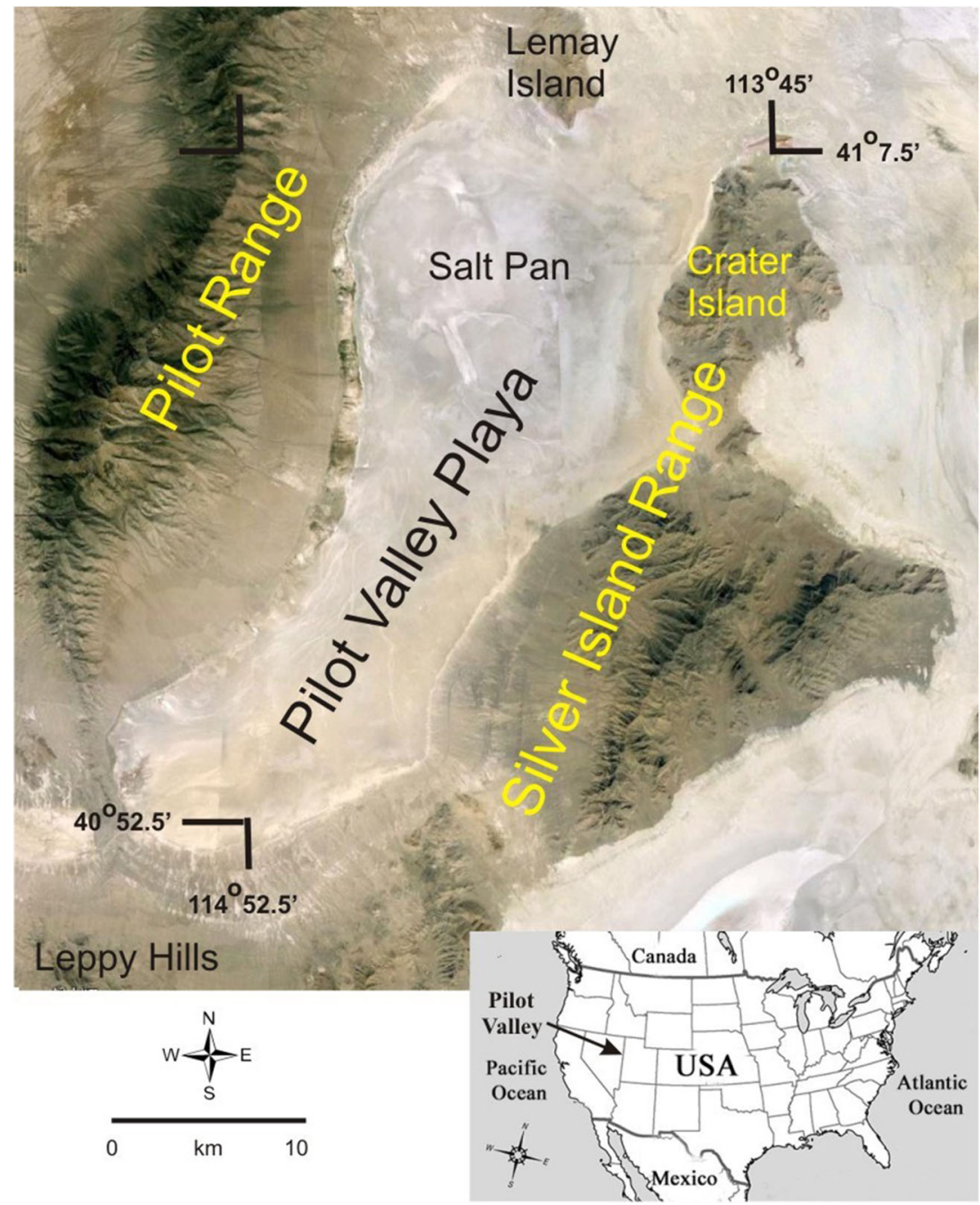


1984, 1985, 1990a, b, 1993; Miller and Lush 1994; Miller and Phelps 2016; Miller et al. 1990, 1993; O’Neil 1968; Schaeffer and Anderson 1960; South et al. 2016). Harrill (1971) and Stephens and Hood (1973) conducted hydrologic reconnaissance investigations. Lines (1979) described the zonation of evaporate minerals and provided an overview of the aquifers. Peterson (1993) undertook the first examination of the shallow groundwater geochemistry. Mason et al. (1995) and Liutkus and Wright (2008) reported some chemical and isotopic data. Carling et al. (2012) investigated Pilot Valley mountain front groundwater recharge and Rey et al. (2016) characterize the shallow basin stratigraphy. The basin margin fresh/salinewater interface has been investigated by Duffy and AlHassan (1988), Oliver (1992), Fan et al. (1997), Winkel (2007), and Mayo et al. (2020).

\section{Methods of investigation}

Field and laboratory investigations included: (1) construction of shallow monitoring wells, (2) water level measurements, (3) mineralogical analysis of lake bed cores, (4) collection and laboratory analysis of stream, spring, and well waters for solutes and isotopes, and (5) geochemical modeling of the fresh to hypersaline groundwater evolution. Solute and isotopic samples were collected from 247 shallow monitoring wells, 16 boreholes, 15 springs, 10 ephemeral streams, and snow. As part of this study, 110 wells and the boreholes were constructed, and the remaining 137 wells were previously constructed (Carling et al. 2012; Mason et al. 1995; Oliver 1992; Peterson 1993). Well depths range from $<1$ to $30 \mathrm{~m}$ below ground surface (bgs). Most wells were completed within $6 \mathrm{~m}$ of the ground surface in hand augured boreholes using $2.54 \mathrm{~cm}$ inside diameter (ID) polyvinyl chloride (pvc) pipe fitted with $0.5 \mathrm{~m}$ of factory slotted screen. Water level measurements were density corrected.

Major sampling campaigns included 2000, 2001, and 2006 for major ions, 2004 for density, and 2002 and 2018 for stable isotopes and tritium. The wells were purged, often to dryness, prior to sampling the following day. Solute and isotopic samples were analyzed at Brigham Young University (USA) facilities for major ions, total dissolved solids (TDS), density, $\delta^{2} \mathrm{H}, \delta^{18} \mathrm{O}, \delta^{13} \mathrm{C},{ }^{3} \mathrm{H}$, and ${ }^{14} \mathrm{C}$. Laboratory instruments included a PerkinElmer 760 AA for cations, a Dionex ICS-90 ion chromatograph for anions, automatic titration for bicarbonate, a Los Gatos cavity-ringdown stable isotope analyzer for $\delta^{2} \mathrm{H}$ and $\delta^{18} \mathrm{O}$, a PerkinElmer Quantalus low activity liquid scintillation counter for tritium, and atomic mass spectrometry (AMS) for carbon-14. Selected wells sampled in 2002 for stable isotopes were resampled in 2018 for $\delta^{2} \mathrm{H}$ and $\delta^{18} \mathrm{O}$ to validate the laboratory results. Wells constructed after the 2002 stable isotopic sampling event were sampled in 2018 for stable isotopes. TDS (mg/L) was calculated by summing the major ion concentrations, whereas temperature-corrected density $\left(\mathrm{g} / \mathrm{cm}^{3}\right)$ was determined for 231 well samples collected in 2004 by mass-volume calculations. $\delta^{2} \mathrm{H}$ and $\delta^{18} \mathrm{O}$ samples were preprocessed by vacuum distillation and tritium samples were electrolytically enriched prior to analysis. Stable isotopes were analyzed relative to the standard VSMOW. Sample locations, well information, and average major ion chemistry and isotopic values are included in the electronic supplemental material (ESM). The mineralogy of sediment samples was determined by $\mathrm{x}$-ray diffraction (XRD) and the computer program RockJock (Eberl 2003). The computer code NETPATH-WIN (El-Kadi et al. 2011) was used to model the geochemical evolution.

\section{Geologic and hydrogeologic setting}

\section{Geology}

The Pilot Valley basin is bounded by Lemay Island to the north, the Pilot Range to the west, the Silver Island Range to the east and southeast, and the Leppy Hills to the south (Fig. 1). The basin is the result of crustal extension block faulting that began about 11 million years ago. The west and east bounding ranges rise to as much as 3,266 m above mean sea level (amsl). The valley floor is $\sim 1,295 \mathrm{~m}$ amsl and slopes gently to the north where it is closed at the low elevation divide between the Lemay and Crater islands. Pleistocene Lake Bonneville communicated with the Pilot Valley embayment thru this divide. The mountain ranges consist of Precambrian metamorphic core complex and Paleozoic carbonate and siliceous bedrock. The valley, a half graben, is filled with as much as 1,600 m of alluvial fan, shoreline, lake bed, and volcanic sediments (Cook et al. 1964; Lines 1979).

The mountain front alluvial fan and pediment surfaces extend 3-5 $\mathrm{km}$ from the mountain bedrock to the edge of the playa. The Pilot Range and Silver Island Range fan surfaces slope values are 0.085 and 0.051 , and encompass about 151 and $87 \mathrm{~km}^{2}$, respectively (Table 1 ). The $379-\mathrm{km}^{2}$ playa basin has been divided into the north, center, and south subbasins (Mayo et al. 2020). The playa slopes gently north and west toward the topographic low in the north subbasin (Fig. 2). A few $\mathrm{cm}$ thick, a $26-\mathrm{km}^{2}$ salt pan covers part of the north subbasin surface (Fig. 1; Table 1). Most of the north and center subbasin surfaces are covered by mud flats containing no vegetation. The north subbasin is nearly flat with elevations ranging from 1,293.5 to 1,295 $\mathrm{m}$ amsl (Fig. 2). The south subbasin is a mud flat that occupies about $90 \mathrm{~km}^{2}$ and is covered by sage bush in the south.

The upper $\sim 4 \mathrm{~m}$ of the basin sediments consists of a postLake Bonneville (Unit I) and Lake Bonneville (units II-IV) stratigraphic units (Fig. 3; Rey et al. 2016). The Lake Bonneville sediments are massive marls with occasional thin 
Table 1 Summary of Pilot Valley precipitation (ppt) based on PRISM 30 year (after Mayo et al. 2020)

\begin{tabular}{llccl}
\hline Region & Type & Area $\left(\mathrm{km}^{2}\right)$ & ppt $\left(10^{6} \mathrm{~m}^{3}\right)$ & $\mathrm{ppt}\left(\mathrm{m}^{3} / \mathrm{km}^{2}\right)$ \\
\hline Pilot Valley & Total & 828.1 & 163.84 & - \\
Pilot Range & Total & 216.0 & 58.37 & 0.27 \\
& Bedrock & 64.6 & 28.39 & 0.44 \\
Silver Island Range & Alluvial fan & 151.4 & 29.98 & 0.20 \\
& Total & 142.5 & 29.4 & 0.21 \\
& Bedrock & 55.2 & 13.69 & 0.25 \\
Leppy Hills & Alluvial fan & 87.3 & 15.71 & 0.18 \\
& Total & 90.7 & 16.3 & 0.18 \\
Playa & Bedrock & 27.0 & 4.86 & 0.18 \\
& Alluvial fan & 63.7 & 11.47 & 0.18 \\
& Total & 378.9 & 55.6 & 0.15 \\
& Salt pan & 26.1 & 4.16 & 0.16 \\
& North and center playa & 263.3 & 42.13 & 0.16 \\
& South playa & 89.5 & 13.43 & 0.15 \\
\hline
\end{tabular}

${ }^{\mathrm{a}}$ Includes salt pan



Elevation ( $\mathrm{m}$ amsl)



Fig. 2 Ground surface elevation of the Pilot Valley playa. Survey locations are shown with dots. All survey locations, shown as dots, are groundwater monitoring wells. Blue-dashed lines are boundaries between subbasins (after Mayo et al. 2020) 


\section{\begin{tabular}{l}
$\quad \therefore$ \\
\hdashline$\quad$ Unit I - Sandy to silty \\
\hdashline$\quad$ Sediment
\end{tabular} \\ Unit II - Yellow gray, massive marl \\ Unit III-b - Olive gray, massive marl}

sandy bed

Unit III-b - Olive gray, massive marl

white laminations

Unit IV - Organic laminated marl

\section{Unit V - Massive oolitic sand}

Fig. 3 Stratigraphic column illustrating the upper $4 \mathrm{~m}$ of the Pilot Valley basin stratigraphy (after Rey et al. 2016). Unit 1 is post-Lake Bonneville, units II-IV are Lake Bonneville, and unit V is a pre-Lake Bonneville oolitic sand. Several meters of pre-Lake Bonneville massive marl underlies unit $\mathrm{V}$

sandy interbeds. A pre-Lake Bonneville oolitic sand (unit V) that is up to $1 \mathrm{~m}$ thick on the basin margins, underlies the Lake Bonneville sequence. Away from the basin margins the unit $\mathrm{V}$ oolitic sand thins. Eight or more meters of pre-Lake
Bonneville blue-colored marl underlies unit V. Except as noted in the following, references to basin sediments refer to stratigraphic units I-V and the pre-Lake Bonneville sequence. The boundary between pre-Lake Bonneville and Lake Bonneville sediments is nominally $3.8 \mathrm{~m}$ below ground surface (bgs). Except for a thin oolitic sand layer in unit III, the post-Lake Bonneville and Lake Bonneville silts, clays, and marls only slowly transmit measurable water. The pre-Lake Bonneville oolitic sand in unit $\mathrm{V}$ generally transmits water freely near the basin margins.

RockJock mineralogical results for shallow basin sediments have been organized into five groups: water transported clay, detrital, carbonate, sulfate, and chloride (Fig. 4). Samples include $0-0.2$ and $0.2-3.5-\mathrm{m}$ bgs depth intervals. The clay and

a) 0-0.2 m depth interval



b) $0.2-3.5 \mathrm{~m}$ depth interval



Fig. 4 Summary of shallow sediment mineralogy organized by sediment class. Alluvial fan and salt pan samples are identified and all other samples are from the shallow basin borings. Clay and alumninosilicate detrital material are allogenic debris transported from the surrounding mountains and alluvial fans. The $0-0.2 \mathrm{~m}$ depth samples include one alluvial fan and three salt pans, and the $0.2-3 \mathrm{~m}$ depth samples include one alluvial fan. Except for the alluvial fan, the carbonate, sulfate and chloride minerals are primarily basin authigenic 
detrital minerals are allogenic. Except for the alluvial fan sample, the carbonate, sulfate, and chloride minerals are authigenic. Clays are predominantly halloysite, Fe-smectite, illite, biotite, Fe-chlorite, and montmorillonite. Most of the detrital minerals are quarts, orthoclase, plagioclase, and ilmenite. Calcite, aragonite, and $\mathrm{Mg}$-calcite are the principal carbonates, gypsum is the principal sulfate, and halite is the principal chloride mineral. On average about $38 \%$ of each nonalluvial fan sample is clay, $28 \%$ is detrital, about $25 \%$ is carbonate, and less than $5 \%$ is sulfate. Halite is about $11 \%$ of the surface samples and is about $4 \%$ of the deeper samples. The alluvial fan sample was collected where the up-gradient terrain was mostly derived from aluminosilicate bedrock with minor contributions from the carbonate terrain. This sample contained as much as $60 \%$ detrital minerals and only about $30 \%$ clay. The upper few $\mathrm{cm}$ of the salt pan is about $50 \%$ halite with the top few $\mathrm{mm}$ of crust consisting of almost entirely halite. Playa near surface clay and aluminosilicate detrital minerals of post-Lake Bonneville unit I sediments are allogenic debris transported from the surrounding mountains and alluvial fans.

\section{Climate and precipitation}

Pilot Valley is an arid region with hot summers and cold winters. Temperature is near freezing in the winter and peaks at about $30^{\circ} \mathrm{C}$ in the summer. Based on data from Wendover, Utah, located 10 miles to the south, the average monthly precipitation is only about $12.1 \mathrm{~cm}$ and precipitation peaks in the spring and fall. Precipitation rates in the high elevations of the Pilot and Silver Island Ranges are appreciably greater than at Wendover. During the spring, summer, and early fall, monthly pan evaporation rates are greater than $200 \mathrm{~mm}$ and peak at $\sim 400 \mathrm{~mm}$ in July and August (Lines 1979).

The Pilot Valley basin average annual precipitation is $159.67 \times 10^{6} \mathrm{~m}^{3}$ (Table 1). The Pilot Range bedrock-alluvial fan and the playa surface each receive about one-third of the total precipitation, and the remaining one-third falls on the combined Silver Island Range and Leppy Hills bedrockalluvial fans. The fate of precipitation falling on the Pilot and Silver Island Ranges is asymmetrical in two aspects. First, some Pilot Range alluvial fan groundwater discharges from springs located at the distal end of the alluvial fan, whereas the Silver Island Range alluvial fan does not support springs. Second, surface flows and playa flooding are annual events from Silver Island Range storms and Pilot Range alluvial fan ephemeral stream flows do not reach the playa. Although about one-third of the total basin precipitation falls on the playa surface, only the north subbasin is partially flooded for a few weeks in most years. This flooding is due to Silver Island Range surface flow, although some Silver Island Range flooding events do not reach the salt pan. Every few years the center subbasin is partially flooded.

\section{Groundwater}

Pilot Valley contains three interconnected groundwater systems: mountain block bedrock, mountain front alluvial fan, and playa basin sediment (Mayo et al. 2020). Only the Pilot Range supports bedrock mountain springs and their discharges are quite small (Peterson 1993). The alluvial fans are recharged by underflow from the bedrock highlands, infiltration of ephemeral surface flows that originate in the bedrock highlands, and by the concentration of local overland alluvial fan flow (Table 2). Total annual bedrock and alluvial fan groundwater recharge is $\sim 5.7 \times 10^{6} \mathrm{~m}^{3}$ of which about $85 \%$ occurs in the Pilot Range. Pilot Range alluvial fan springs discharge at or near the alluvial fan-playa interface and are referred to herein as interface springs. Measured spring flow rates range from $<1$ to $\sim 30 \mathrm{~L} / \mathrm{s}$ and many spring areas do not have surface discharge, but are covered by meadow grass and other hydrophytes. About $31 \%\left(1.7410^{6} \mathrm{~m}^{3}\right)$ of Pilot Range bedrock and alluvial fan groundwater discharges at the 50 plus interface springs (Fig. 5) and $\sim 64 \%\left(\sim 2.5 \times 10^{6}\right.$ $\mathrm{m}^{3}$ ) of the groundwater underflows to shallow basin sediments. By contrast only about $0.82 \times 10^{6} \mathrm{~m}^{3}$ of Silver Island Range bedrock and alluvial fan groundwater underflows to the basin sediments.

Although there is considerable annual water contribution to the playa surface from direct precipitation $\left(55.6 \times 10^{6} \mathrm{~m}^{3}\right.$; Table 1) and surface runoff from the Silver Island Range $\left(0.66 \times 10^{6} \mathrm{~m}^{3}\right)$, this water is mostly consumed by evaporation as the basin is closed to surface and groundwater outflow, and vegetation is limited in the south subbasin and absent elsewhere. The potential for recirculation of playa surface water to the shallow basin sediments and then back to the surface for evaporation is discussed in the following.

Two shallow groundwater systems have been identified in the basin sediments (Mayo et al. 2020). The systems are the Lake Bonneville sediments and the pre-Lake Bonneville sediments, which correspond to approximately $0-3.8$ and 3.8$12 \mathrm{~m}$ bgs, respectively. Except for some basin margin areas the groundwater systems are leaky confined. The general groundwater flow direction is from the alluvial fan-playa interfaces to the subbasins, from the south subbasin to the center subbasin, and then to the north subbasin (Fig. 6). In addition to the northerly flow the dominant groundwater flow direction in the center subbasin is westward from the Silver Island Range alluvial fan toward the Pilot Range alluvial fan (Fig. 7). This westerly flow is the result of the gentle westward tilt of the basin due Basin and Range faulting. Along the $\mathrm{A}-\mathrm{A}^{\prime}$ profile, as elsewhere in the basin, there are upward vertical groundwater gradients from the pre-Lake Bonneville sediments to the Lake Bonneville sediments. Vertical gradients have been calculated for nested well pairs using up to 15 years of data for center and north subbasin wells. Excluding wells located at the alluvial fan-playa interface, the average upward gradients 
Table 2 Pilot Valley annual water budget (modified after Mayo et al. 2020)

\begin{tabular}{|c|c|c|c|c|}
\hline Water budget component & $\begin{array}{l}\text { Precipitation } \\
\left(10^{6} \mathrm{~m}^{3}\right)\end{array}$ & $\begin{array}{l}\text { Recharge } \\
\left(10^{6} \mathrm{~m}^{3}\right)\end{array}$ & $\begin{array}{l}\text { Subregion total } \\
\text { precipitation } \\
\left(10^{6} \mathrm{~m}^{3}\right)\end{array}$ & $\begin{array}{l}\text { Subregion percent } \\
\text { of basin total } \\
\text { precipitation }\end{array}$ \\
\hline \multicolumn{5}{|l|}{ Precipitation } \\
\hline Pilot Range bedrock & 28.39 & - & - & - \\
\hline Pilot Range alluvial fan & 29.97 & - & - & - \\
\hline - Pilot Range subtotal & - & - & 58.36 & 0.37 \\
\hline Silver Island Range bedrock & 13.69 & - & - & - \\
\hline Silver Island Range alluvial fan & 15.71 & - & - & - \\
\hline - Silver Island Range subtotal & - & - & 29.40 & 0.18 \\
\hline Leppy Hills bedrock & 4.86 & - & - & - \\
\hline Leppy Hills alluvial fan & 11.47 & - & - & - \\
\hline - Leppy Hills subtotal & - & - & 16.33 & 0.10 \\
\hline Playa salt pan & 4.16 & - & - & - \\
\hline North and center playa subbasins including salt pan & 42.08 & - & - & - \\
\hline South playa subbasin & 13.5 & - & - & - \\
\hline - Playa total & 55.58 & - & 55.58 & 0.35 \\
\hline Total annual precipitation & 159.67 & - & - & - \\
\hline \multicolumn{5}{|l|}{ Groundwater recharge } \\
\hline \multicolumn{5}{|l|}{ Pilot Range } \\
\hline - Pilot Range bedrock & - & 4.032 & - & - \\
\hline - Pilot Range alluvial fan & - & 0.755 & - & - \\
\hline - Pilot Range spring discharge & - & -1.742 & - & - \\
\hline - Pilot Range export to Wendover & - & -0.350 & - & - \\
\hline - Pilot Range irrigation & - & -0.247 & - & - \\
\hline - Pilot Range fan underflow to the playa & - & 2.448 & - & - \\
\hline \multicolumn{5}{|l|}{ Silver Island Range } \\
\hline - Silver Island Range bedrock & - & 0.421 & - & - \\
\hline - Silver Island Range alluvial fan & - & 0.396 & - & - \\
\hline - Silver Island Range underflow to playa & - & 0.817 & - & - \\
\hline - Silver Island Range surface runoff to playa & - & 0.663 & - & - \\
\hline \multicolumn{5}{|l|}{ Leppy Hills } \\
\hline - Leppy Hills bedrock and alluvial fan underflow to the playa & - & 0.049 & - & - \\
\hline Playa & - & - & - & - \\
\hline - Playa infiltration & - & $?$ & - & - \\
\hline
\end{tabular}

in the north and center subbasins are 0.0135 and 0.0139 , respectively. Upward gradient persist throughout the year.

What is particularly interesting about the westward groundwater flow in the center subbasin is the fact that at the Pilot Range alluvial fan-playa interface there is an inverted salinity gradient (Fig. 8) and a north-south trending, linear pressure ridge of freshwater beneath the overlying brine. Mayo et al. (2020) found that the east flowing freshwater in the deeper coarse grained Pilot Range alluvial fan sediments has sufficient hydraulic head, velocity, and flux to keep the west flowing basin sediment brine at bay, while the velocity and flux of the freshwater in the overlying clays are not sufficient to prevent the west movement of shallow brine at the transition zone. They further found that the pressure ridge was the result of an osmotic pressure condition between the deeper less saline water and overlying brine in the clay-rich sediments.

\section{Results}

Average major ion concentrations, $\delta{ }^{13} \mathrm{C},{ }^{3} \mathrm{H}$ and ${ }^{14} \mathrm{C}$, results for streams, springs, mountain block, alluvial fan-playa interfaces, and basin sediments are listed in Table 3 . Average stable isotopic data $\left(\delta^{2} \mathrm{H}\right.$ and $\left.\delta^{18} \mathrm{O}\right)$ data values for each sampling location are included in the ESM.

Density is the preferred salinity measure because most of the shallow groundwaters are saline to hypersaline (Fig. 9). Brine and hypersaline are considered herein as 100,000$200,000 \mathrm{mg} / \mathrm{L}\left(\sim 1.068-1.135 \mathrm{~g} \mathrm{~cm}^{3}\right)$ and $>200,000 \mathrm{mg} / \mathrm{L}$ $\left(1.135 \mathrm{~g} \mathrm{~cm}^{3}\right)$, respectively. The shallow groundwater has been organized into six geochemical endmember groups: (1) alumninosilicate mountain bedrock and alluvial fan, (2) carbonate mountain bedrock and alluvial fan, (3) north subbasin alluvial fan-playa interface, (4) center subbasin alluvial fanplaya interface, (5) south subbasin alluvial fan-playa interface, and (6) basin sediments. Pre-Lake Bonneville and Lake Bonneville basin sediment groundwaters are combined and organized by density. The five density groups are: 1.0-1.01, $1.01-1.05,1.05-1.10,1.10-1.15$, and $1.15-1.21 \mathrm{~g} / \mathrm{cm}^{3}$. The average isotopic and major ion composition of each of these water types are summarized in Table 3.

The Pilot Range aluminosilicate mountain bedrock springs discharge mixed anion- $\mathrm{HCO}_{3}$ type water with an average TDS of $53 \mathrm{mg} / \mathrm{L}$, and the carbonate bedrock springs discharge 
Fig. 5 Locations of springs and seeps that discharge the distal at the alluvial fan-playa interface. Springs are shown as filled circle with a tail



$\mathrm{Ca}-\mathrm{HCO}_{3}$ type water with an average TDS of $212 \mathrm{mg} / \mathrm{L}$ (Table 3; Fig. 10). The waters are undersaturated with respect to all mineral species of interest (Fig. 11). Because direct measurements of alluvial fan groundwater chemistry are not possible, bedrock aluminosilicate and carbonate spring water chemistries are assigned as surrogates for their respective alluvial fan groundwaters. The chemistry of Pilot Range carbonate bedrock groundwater is also a reasonable surrogate for the Silver Island Range alluvial fan groundwater chemistry. Ephemeral Pilot Range alluvial fan streams contain $\mathrm{Ca}$ $\mathrm{HCO}_{3}$ type water with an average TDS of $71 \mathrm{mg} / \mathrm{L}$. The waters are undersaturated with respect to carbonate, chloride, and sulfate minerals.

The interface springs become progressively more saline from north to south (Fig. 12). North subbasin springs discharge fresh (TDS 261-469 mg/L) mixed cation-anion type water (Table 3 ). Center subbasin springs discharge brackish (TDS $\sim 1,200-1,400 \mathrm{mg} / \mathrm{L}$ ) Na-Cl type water containing lessor amounts of $\mathrm{Ca}^{2+}, \mathrm{Na}^{+}$, and $\mathrm{HCO}_{3}{ }^{-}$, and south subbasin springs discharge saline (TDS $\sim 9,000-21,000 \mathrm{mg} / \mathrm{L}$ ) $\mathrm{Na}-\mathrm{Cl}$ type waters. The potassium in both the center and south subbasin spring waters are elevated and the reacting equivalents of $\mathrm{K}^{+}$in the south subbasin springs exceed the reacting equivalents of $\mathrm{SO}_{4}{ }^{2-}$. The north and center subbasin interface spring waters are undersaturated with respect to all mineral species of interest, whereas the south subbasin springs are supersaturated with respect to carbonate minerals (Fig. 11).

Regardless of density, all playa basin sediment groundwaters are $\mathrm{Na}-\mathrm{Cl}$ type with $\mathrm{Na}^{+}$and $\mathrm{Cl}^{-}$concentrations ranging from $\sim 45$ to 4,035 and $\sim 43$ to $4,720 \mathrm{meq} / \mathrm{L}$, respectively (Table 3 ). Density increases generally parallel to the groundwater flow direction with freshwater near the basin margins evolving to hypersaline in the north and center subbasins (Fig. 13). In Pilot Valley, density is a better indicator of groundwater flow direction than single-event water level measurements, because in the closed basin environment salinity 


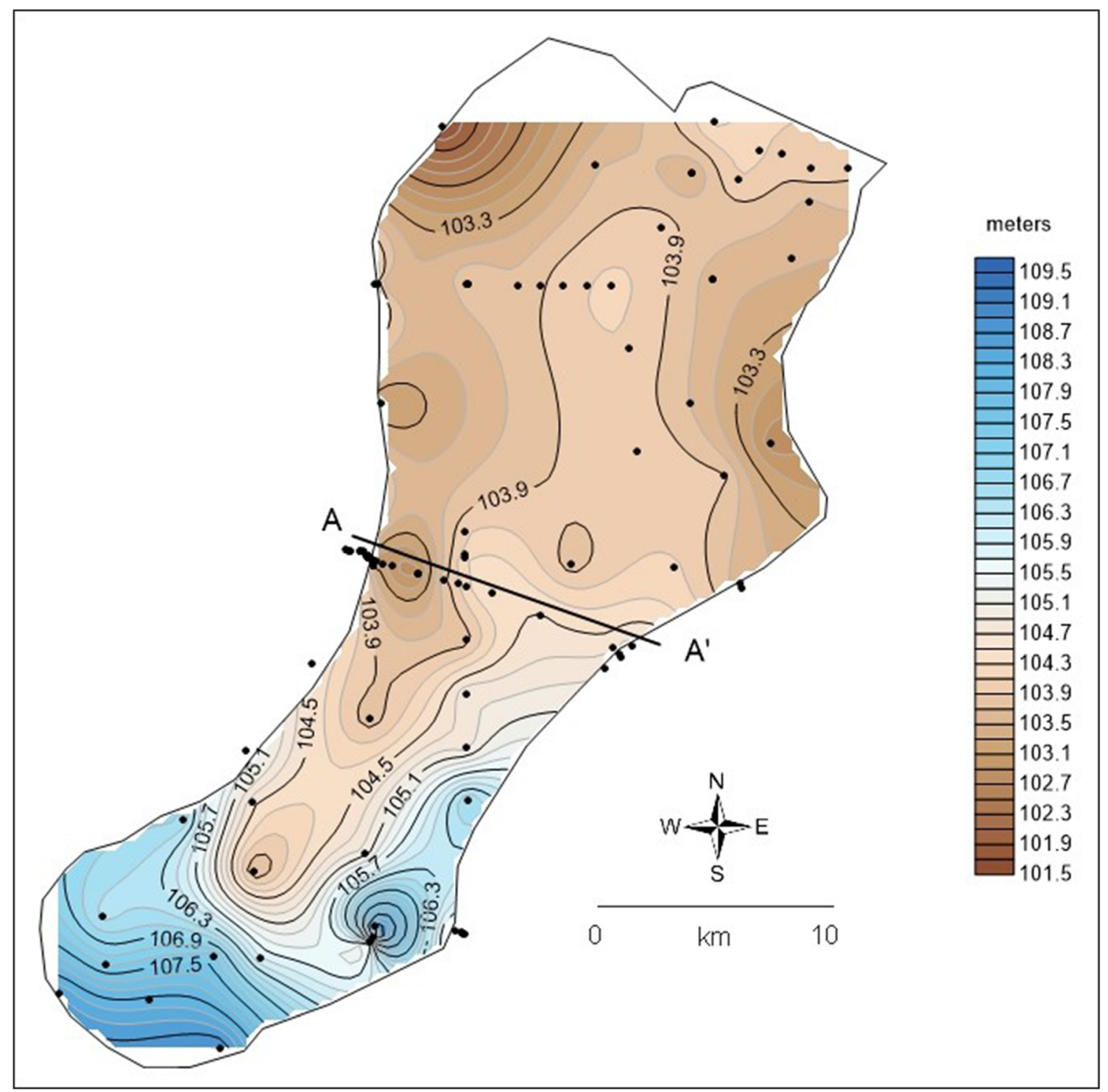

Fig. 6 Contour map of May 2014 density-corrected groundwater levels in Lake Bonneville sediments. Elevations are relative to an arbitrary $100 \mathrm{~m}$ datum. The $100 \mathrm{~m}$ datum corresponds to $1,290 \mathrm{~m}$ amsl. Well

reflects the accumulated contact with soluble salts along the groundwater flow path. The density contours show an evolution from less saline water in the south subbasin and basin margins to more saline water in the western side of the center subbasin and at the topographic low in the north subbasin.

Based on average major ion compositions, all basin sediment groundwater density groups are saturated or supersaturated with respect to carbonate minerals (Fig. 11). Groundwaters with density $<1.15 \mathrm{~g} / \mathrm{cm}^{3}$ are undersaturated with respect to sulfate and chloride minerals. In the north subbasin the Lake Bonneville sediment, groundwaters become both halite and gypsum saturated with the area of gypsum saturation appreciably larger than the area of halite saturation (Fig. 14). Although there are not sufficient data to draw saturation index (SI) contours for pre-Lake Bonneville locations are shown with filled circles. The center subbasin section A$\mathrm{A}^{\prime}$ is used in Figs. 7, 8, 16, 17, and 18 (Modified after Mayo et al. 2020)

sediment groundwater, the available data suggests that the waters are gypsum supersaturated and halite undersaturated in the central area of the north subbasin.

Stable isotopic data for 127 precipitation samples collected from seven Silver Island Range continuous collectors, three Pilot Range ephemeral streams, seven Pilot Range alluvial fan springs, and 126 basin wells and boreholes are plotted relative to the Global Meteoric Water Line (GMWL; Fig. 15). The precipitation, spring, and stream data plot parallel to the GMWL (Fig. 15a). Most precipitation $\delta^{18} \mathrm{O}$ data fall in the broad range of about of -17 to $-9 \%$, and the spring and stream data fall near the more negative portion of the GMWL with average $\delta^{18} \mathrm{O}$ and $\delta^{2} \mathrm{H}$ values of -14.8 and $117.3 \%$, respectively. Much of the groundwater in both Lake Bonneville and pre-Lake Bonneville sediments contain 
Fig. 7 Average water level profiles across the center subbasin. See Fig. 6 for profile location. Distances are relative to an arbitrary alluvial fan location known as Truck Springs (UTM Zone 12 , northing 4,544,328, easting 250,088)

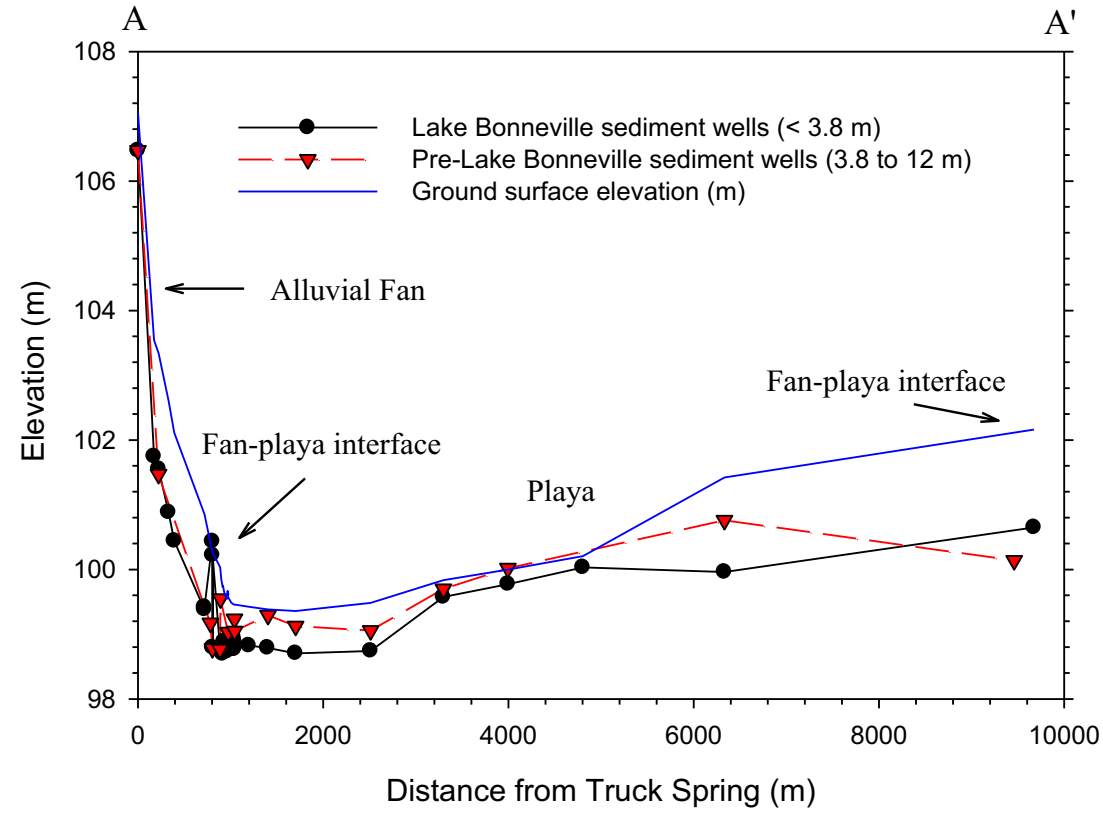

apparent evaporated water. Waters with $\delta^{18} \mathrm{O}<-11$ to $-10 \%$ o are considered to be apparently evaporated. Apparent evaporated water includes groundwater in pre-Lake Bonneville sediments and a sample from a basin well screened at $\sim 30 \mathrm{~m}$ bgs (Fig. 15b).

Nonevaporative groundwater evolves to apparent strongly evaporative groundwater from the basin margins to the center of the north and center subbasins in Lake Bonneville sediment groundwaters (Fig. 16a). A similar trend may exist in the preLake Bonneville sediment groundwater (Fig. 16b), but the data are too limited to confirm this. To better visualize the evolution to apparent evaporated groundwater the $\delta^{18} \mathrm{O}$ data for both Lake Bonneville and pre-Lake Bonneville sediments that lie along a linear trend from the distal end of the Pilot Range alluvial fan to the Silver Island Range fan-playa interface in the center subbasin is plotted in Fig. 17. Groundwater in the
Pilot Range alluvial fan-playa interface is nonevaporated, water beneath the playa is apparently evaporated, and groundwater at the Silver Island Range fan-playa interface is transitioning from nonevaporated to apparent evaporated. At the boundary between the Pilot Range fan-playa interface and the playa there is an abrupt change from nonevaporated to apparent evaporated groundwater (Fig. 18). Over a horizontal distance of only about $100 \mathrm{~m}$ there is a remarkable $\sim 8 \%$ change in $\delta^{18} \mathrm{O}$ from approximately -15 to $-7 \%$ o. About $400 \mathrm{~m}$ east of the playa margin the $\delta^{18} \mathrm{O}$ is only about $-3 \%$. The shift from nonevaporated to apparent evaporated groundwater near the boundary of alluvial fan-playa interface and the playa involves both Lake Bonneville and pre-Lake Bonneville sediments groundwater, including wells that are screened at $14.5-30 \mathrm{~m}$ bgs. All of the wells at the interface boundary are screened more than $1.5 \mathrm{~m}$ bgs and most are screened more than $2 \mathrm{~m}$ bgs.
Fig. 8 Total dissolved solids (TDS) contour profile at the Pilot Range alluvial fan-playa interface showing inverted density profile with elevated TDS water overriding lower TDS water. freshwater flow is from the left (Pilot Range alluvial fan) and high salinity flow is from the right (basin). The profile location coincides with the $\mathrm{A}-\mathrm{A}^{\prime}$ profiles in Fig. 7. Modified after Mayo et al. (2020)
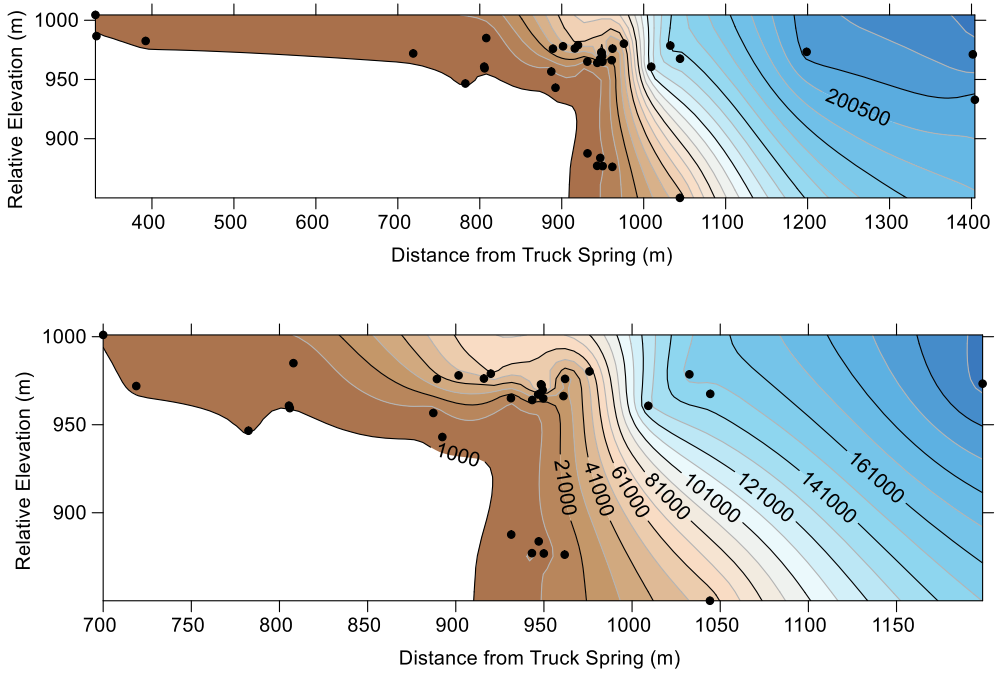

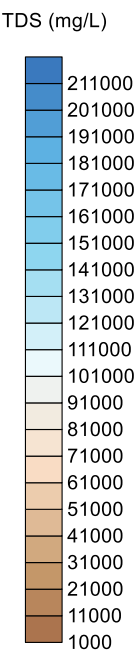


Table 3 Average chemical compositions of Pilot Valley groundwater systems. End-member average values

\begin{tabular}{|c|c|c|c|c|c|c|c|c|c|c|c|c|c|c|}
\hline Water budget component & $\begin{array}{l}\mathrm{T} \\
\left({ }^{\circ} \mathrm{C}\right)\end{array}$ & $\mathrm{pH}$ & $\begin{array}{l}\delta^{13} \mathrm{C} \\
(\% o)\end{array}$ & $\begin{array}{l}{ }^{3} \mathrm{H} \\
\text { (TU) }\end{array}$ & $\begin{array}{l}{ }^{14} \mathrm{C} \\
(\mathrm{pmc})\end{array}$ & $\begin{array}{l}{ }^{14} \mathrm{C} \text { age } \\
\text { (years } \mathrm{BP} \text { ) }\end{array}$ & $\begin{array}{l}\text { TDS } \\
\left(\mathrm{mg} \mathrm{L}^{-1)}\right.\end{array}$ & $\begin{array}{l}\mathrm{Ca} \\
\text { meq L }\end{array}$ & ${ }_{-1} \mathrm{Mg}$ & $\mathrm{Na}$ & $\mathrm{K}$ & $\mathrm{HCO}_{3}$ & $\mathrm{Cl}$ & $\mathrm{SO}_{4}$ \\
\hline \multicolumn{15}{|l|}{ Stream } \\
\hline Pilot Range alluvial fan & 7.8 & 8.2 & -11.0 & 9.6 & - & - & 71 & 0.65 & 0.10 & 0.13 & 0.02 & 0.80 & 0.05 & 0.05 \\
\hline \multicolumn{15}{|l|}{ Pilot Range spring-alluvial fan } \\
\hline Aluminosilicate & 9.4 & 6.9 & - & - & - & - & 53 & 0.40 & 0.10 & 0.20 & 0.00 & 0.50 & 0.10 & 0.10 \\
\hline Carbonate & 10.0 & 7.2 & - & - & - & - & 212 & 1.93 & 0.47 & 0.31 & 0.05 & 2.43 & 0.12 & 0.13 \\
\hline \multicolumn{15}{|c|}{ Pilot Range alluvial fan-playa interface } \\
\hline North subbasin & 14.6 & 7.9 & -8.6 & - & - & - & 361 & 1.55 & 0.70 & 2.86 & 0.27 & 2.14 & 2.63 & 0.42 \\
\hline Center subbasin & 15.0 & 7.9 & -6.6 & - & - & - & 1,277 & 2.32 & 1.23 & 15.37 & 0.69 & 3.25 & 16.84 & 0.81 \\
\hline South subbasin & 14.9 & 7.9 & -7.7 & - & - & - & 15,327 & 20.51 & 11.26 & 210.25 & 11.59 & 3.64 & 251.07 & 7.54 \\
\hline \multicolumn{15}{|c|}{ Basin sediment groundwater density $\left(\mathrm{g} / \mathrm{cm}^{3}\right)$} \\
\hline 1.00 & 12.3 & 8.0 & - & - & - & - & 3,586 & 5 & 4 & 45 & 2 & 8 & 43 & 6 \\
\hline $1.01-1.05$ & 12.4 & 7.6 & - & - & - & - & 44,069 & 21 & 28 & 655 & 23 & 7 & 708 & 33 \\
\hline $1.05-1.10$ & 13.0 & 7.3 & -8.3 & - & - & - & 114,655 & 49 & 78 & 1,755 & 69 & 4 & 1,885 & 54 \\
\hline $1.10-1.15$ & 12.9 & 7.4 & -4.3 & - & - & - & 203,539 & 82 & 173 & 3,004 & 127 & 3 & 3,472 & 50 \\
\hline $1.15-1.21$ & 12.9 & 6.9 & -4.8 & - & - & - & 275,901 & 111 & 204 & 4,035 & 213 & 2 & 4,720 & 54 \\
\hline \multicolumn{15}{|c|}{ Pilot Range alluvial fan-playa interface springs } \\
\hline \multicolumn{15}{|l|}{ North subbasin } \\
\hline AS 2 & 13.0 & 7.8 & -10.9 & - & - & - & 261 & 1.62 & 0.47 & 1.43 & 0.18 & 2.05 & 1.19 & 0.30 \\
\hline AS 3 & 14.8 & - & - & - & - & - & 285 & 0.84 & 0.40 & 2.86 & 0.13 & 1.78 & 1.85 & 0.37 \\
\hline AS 6 (Tessa) & 15.4 & 8.1 & -7.5 & $<0.3$ & 35.3 & 2100 & 458 & 1.49 & 0.96 & 3.38 & 0.65 & 2.90 & 3.04 & 0.58 \\
\hline AS 7 & 15.1 & - & -7.5 & - & - & - & 469 & 1.97 & 0.95 & 4.51 & 0.24 & 1.44 & 5.33 & 0.54 \\
\hline AS 11 (South Patterson) & 14.5 & 7.8 & - & 2.6 & - & - & 333 & 1.84 & 0.73 & 2.13 & 0.13 & 2.52 & 1.75 & 0.34 \\
\hline \multicolumn{15}{|l|}{ Center subbasin } \\
\hline AS 1 (Halls Meadow) & 15.3 & 7.9 & -4.2 & 0.3 & 25.1 & 3100 & 1,172 & 0.70 & 0.49 & 15.59 & 0.56 & 3.69 & 14.13 & 0.93 \\
\hline AS 4 (Muncie) & 15.0 & 7.6 & -5.3 & $<0.3$ & - & - & 1,258 & 0.78 & 0.57 & 17.26 & 0.78 & 3.52 & 15.34 & 1.01 \\
\hline AS 10 (Donner) & 14.7 & 8.3 & -10.3 & 4.1 & - & - & 1,401 & 5.47 & 2.64 & 13.27 & 0.73 & 2.52 & 21.03 & 0.47 \\
\hline \multicolumn{15}{|l|}{ South subbasin } \\
\hline AS 05 (North Little Salt) & 15.2 & 8.8 & - & 1.9 & - & - & 15,982 & 18.74 & 9.79 & 222.89 & 12.36 & 3.70 & 263.26 & 6.56 \\
\hline AS 09 (Little Salt) & 15.0 & 7.1 & -4.8 & 4.0 & - & - & 20,842 & 21.53 & 16.56 & 286.06 & 16.53 & 2.79 & 344.78 & 12.17 \\
\hline AS 12 & 14.6 & - & -10.7 & - & - & - & 9,158 & 21.27 & 7.43 & 121.80 & 5.89 & 4.44 & 145.17 & 3.88 \\
\hline
\end{tabular}

Tritium samples were analyzed for two streams, two alluvial fan wells, seven interface springs, and basin groundwaters in 27 Lake Bonneville and 18 pre-Lake Bonneville sediment wells (Table 3; Fig. 19). Carbon-14 was analyzed for two interface springs and one alluvial fan well. Regardless of playa location almost all groundwater in both Lake Bonneville and pre-Lake Bonneville sediments contain measurable tritium. Pre-Lake Bonneville sediment groundwater has an average of $1.52 \pm 1.57 \mathrm{TU}$ with two of the samples having less than the minimum detection limit (mdl) of $0.3 \mathrm{TU}$. Lake Bonneville sediment groundwater has an average of $3.58 \pm$ 2.5 TU with two samples containing less than the mdl. The interface springs contain between $<0.3$ and $4.1 \mathrm{TU}$. Two north and center subbasin interface springs with $0.3 \mathrm{TU}$ or less (i.e., AS-6 Tessa, and AS-1 Halls Meadow) have calculated ${ }^{14} \mathrm{C}$ ages of 3,100 and 2,100 years BP, respectively (Table 3 ). Groundwater in a 30-m deep irrigation well in the Pilot
Range alluvial fan contains 58\% modern carbon (pmc) and has a calculated ${ }^{14} \mathrm{C}$ age of modern.

Tritium data are not available for local precipitation; however, Lindon, Utah, precipitation data are a reasonable surrogate for Pilot Valley in that Lindon has a similar physiographic position and receives precipitation from the same storm tracks as Pilot Valley. The median Lindon ${ }^{3} \mathrm{H}$ in 79 samples collected between 2002 and 2012 is $7.6 \mathrm{TU}$ (average $8.5 \mathrm{TU}$ \pm 4.8 ; Mayo and Tingey 2021).

\section{Analysis and discussion}

\section{Basin margin groundwater}

The ${ }^{3} \mathrm{H}$ in the interface springs suggests two different alluvial fan groundwater flow-path travel times. One group of springs 
Fig. 9 Scatter plot of TDS vs density of shallow Pilot Valley groundwater. The division between brine and hypersaline is set herein at $\sim 200,000 \mathrm{mg} / \mathrm{L}$ or $1.14 \mathrm{~g} / \mathrm{cm}^{3}$



contains $0.4 \mathrm{TU}$ or less and the other group contains $\sim 2$ or more TU (Table 3; Fig. 19). Assuming closed system conditions and that the typical Pilot Valley precipitation has $\sim 8 \mathrm{TU}$, the average ${ }^{3} \mathrm{H}$ travel time for groundwater with $<0.4 \mathrm{TU}$ is greater than 50 years and groundwater with 1.9-4.1 TU has ${ }^{3} \mathrm{H}$ travel times of $\sim 12-24$ years. Travel times are independent of upgradient bedrock catchment size and flow path lithology. Springs with $<0.4 \mathrm{TU}$ have bedrock catchments ranging from 1.6 to $6.1 \mathrm{~km}^{2}$ and springs with 1.9 or more TU have bedrock catchments ranging from 1.0 to $5.2 \mathrm{~km}^{2}$. Waters with low and elevated ${ }^{3} \mathrm{H}$ are associated with both freshwater in north subbasin springs and slightly brackish water in the center subbasin springs. The tritium content of north subbasin springs AS 6 $(<0.3 \mathrm{TU})$ and AS 11 (2.6 TU) are particularly interesting. Because their groundwater flows are restricted to relatively steep alluvial fan clastic sediments, retardation in finergrained saline lake bed sediments located near the alluvial fan-playa interface cannot be the cause of the travel time
Fig. 10 Trilinear diagram of Pilot Range ephemeral stream and alluvial fan-playa interface springs

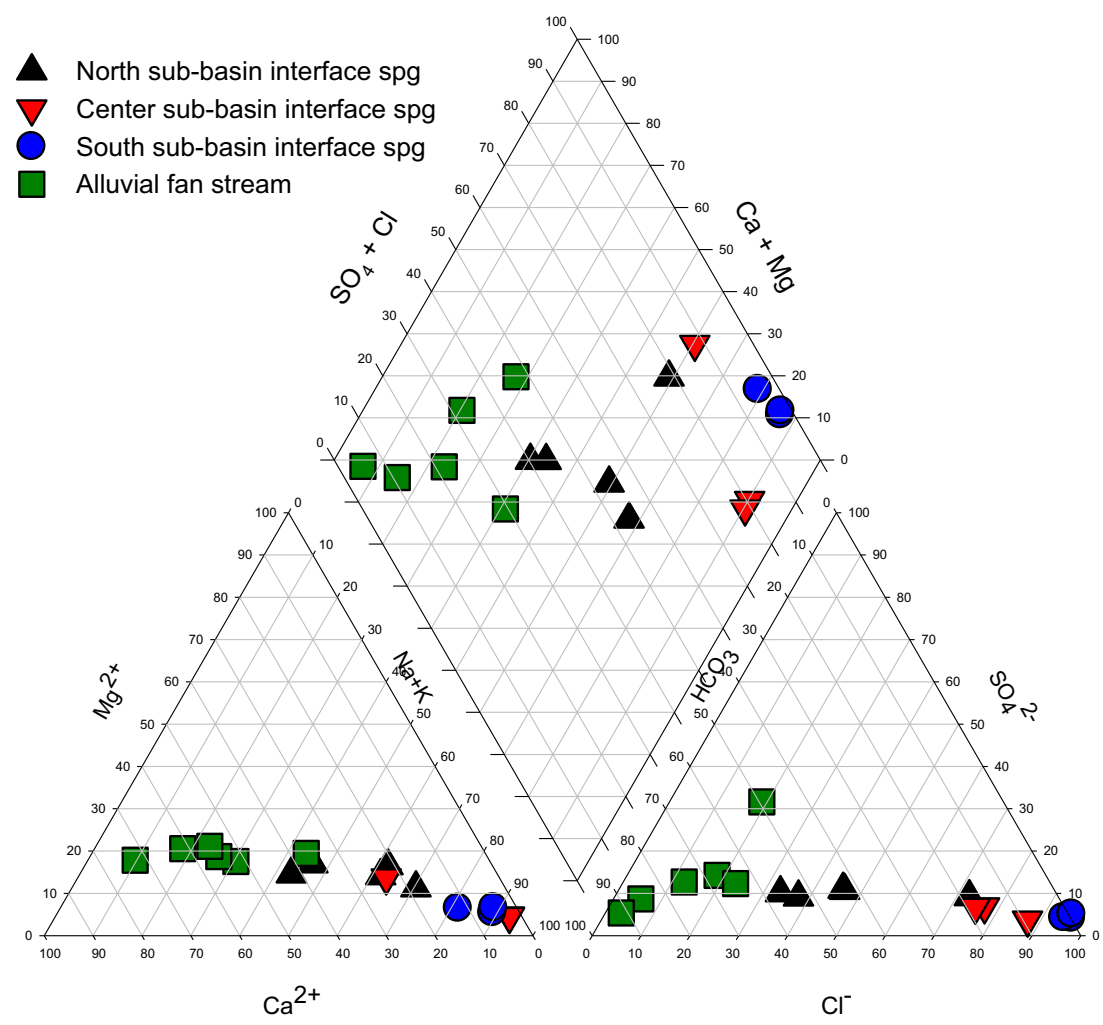


Fig. 11 Saturation indices of average stream and groundwater water quality. Mountain block spring water discharging from alumninosilicate and carbonate bedrock are surrogates for their respective alluvial fan waters.

North, center and south subbasin springs discharge at the Pilot Range alluvial fan-playa interface. Basin groundwater densities are in $\mathrm{g} / \mathrm{cm}^{3}$. Saturation $=0.0 \pm 0.1$, under saturation $<-0.1$, and supersaturation $>0.1$

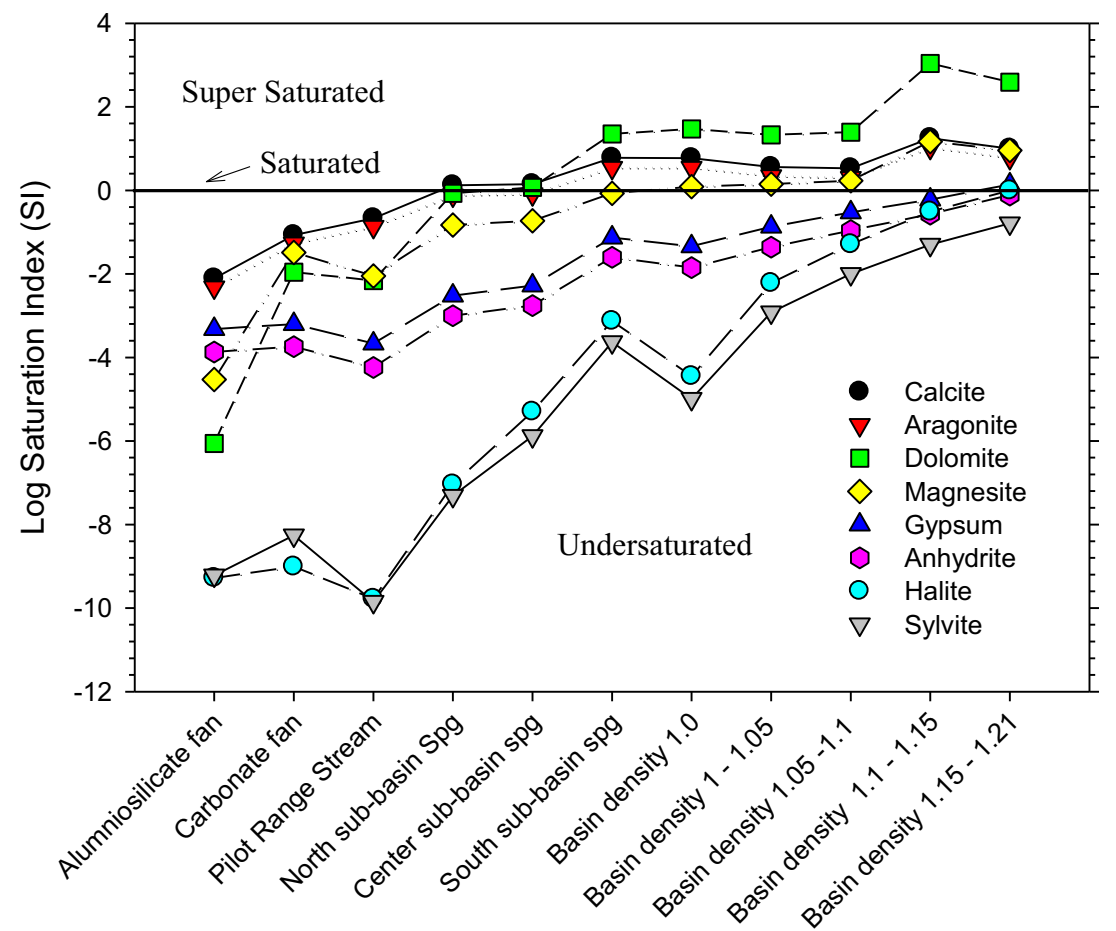

differences. Some center subbasin springs, which likely have contact with saline lakebed sediments, also have dissimilar ${ }^{3} \mathrm{H}$ contents. Both AS 1 and AS 4 have apparent ${ }^{3} \mathrm{H}$ travels times $>50$ years, whereas AS 10 has a ${ }^{3} \mathrm{H}$ travel time of $\sim 12$ years.

The very low ${ }^{3} \mathrm{H}$ content and the calculated ${ }^{14} \mathrm{C}$ ages of $\sim 2,000-3,000$ years BP of many interface springs are unexpected. The small ${ }^{3} \mathrm{H}$ contents in some interface springs suggests that the extremely slow shallow alluvial fan groundwater flow is isolated from modern groundwater recharge along much of the relatively short $(3-5 \mathrm{~km})$ and steep alluvial fans, and that inflows from ephemeral alluvial fan streams are not a major recharge source for this group of older alluvial fan groundwater. The fact that $\sim 84 \%$ of the calculated Pilot Range groundwater recharge occurs in the bedrock highlands before
Fig. 12 Stiff diagrams of springs discharging at the Pilot Range alluvial fan-playa interface. Arrows indicate alluvial fan groundwater flow directions. The groundwater flow for south subbasin springs AS 9 and AS 12 originate in the Pilot Creek Valley, located to the west

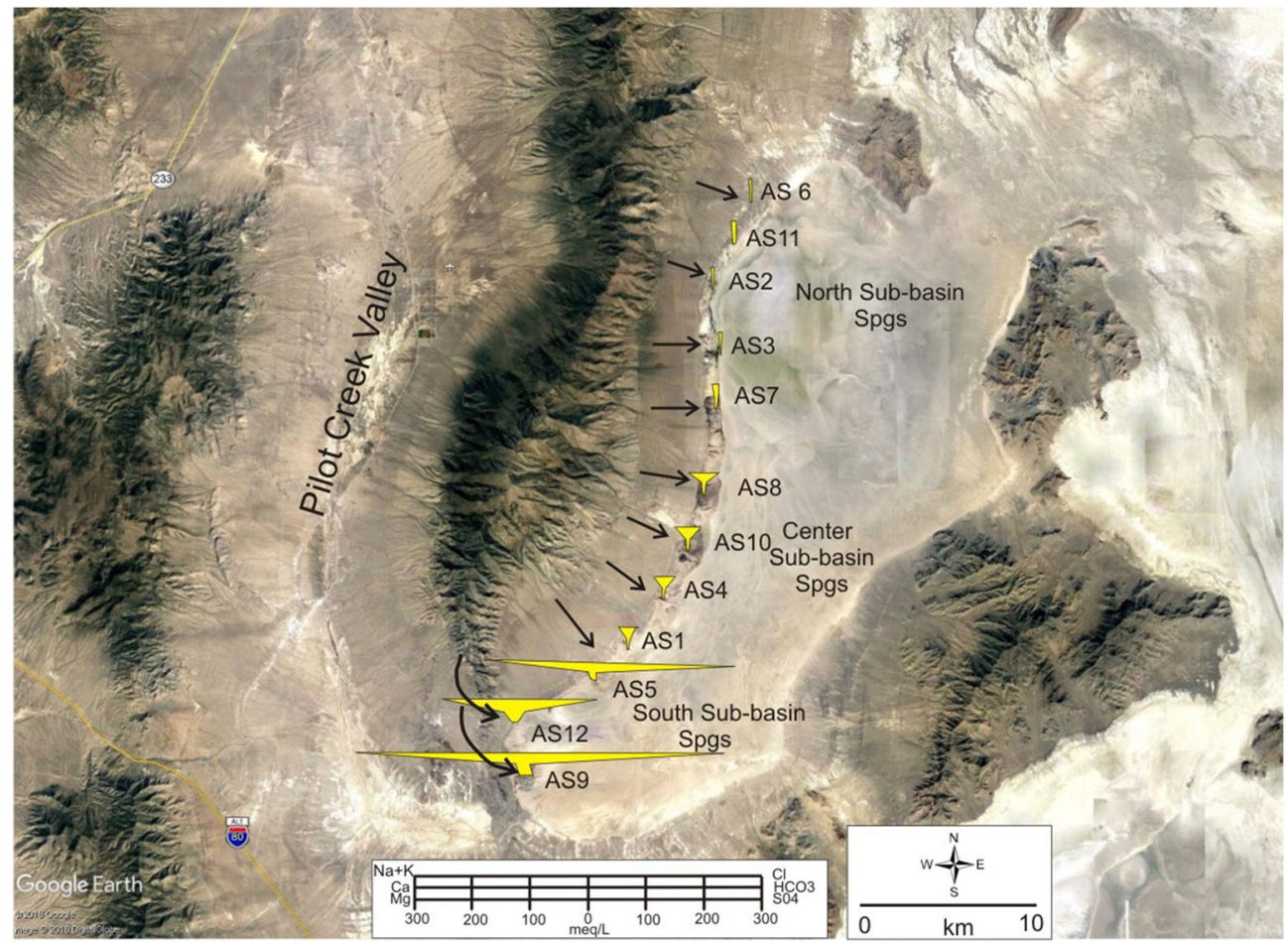


a)

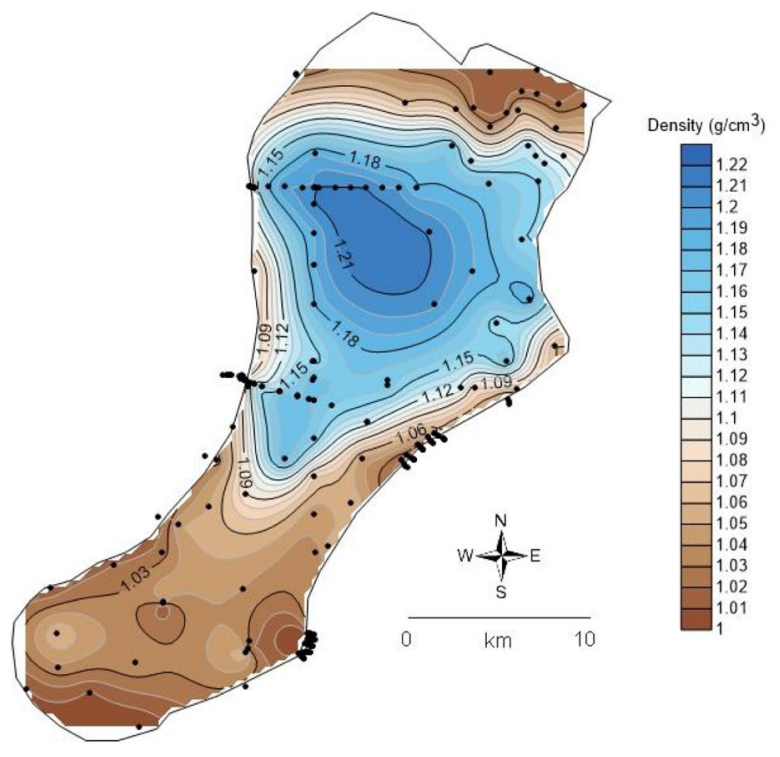

b)

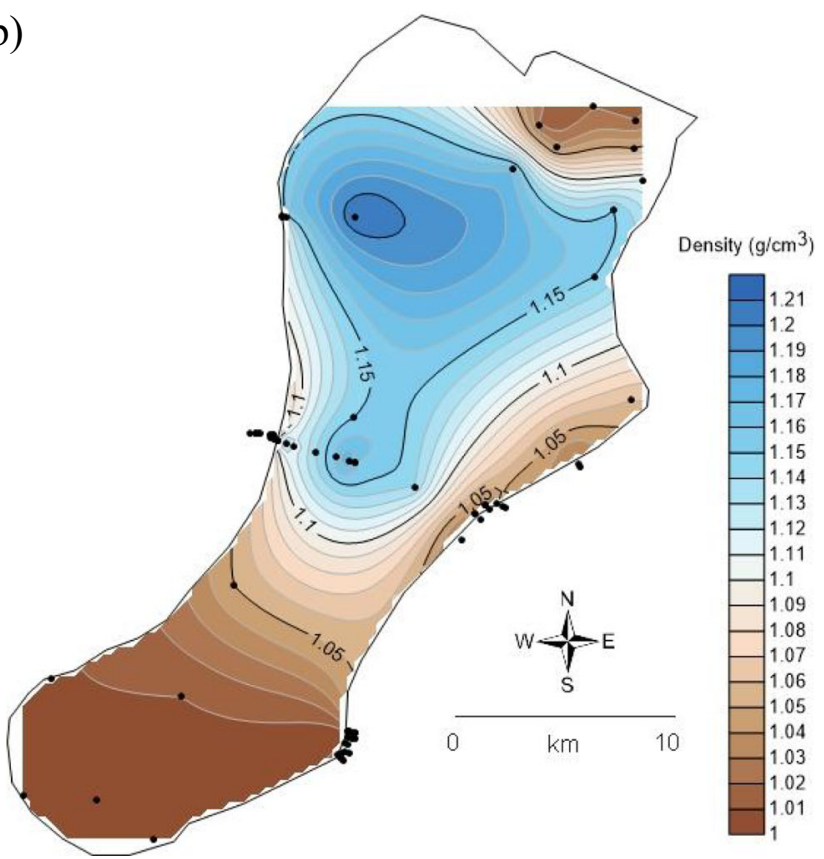

Fig. 13 Groundwater density contour maps of average a pre-Lake Bonneville sediment groundwater, and $\mathbf{b}$ Lake Bonneville sediments groundwater. Well locations are shown as filled circles

underflowing to the alluvial fans (Table 2) may account for the ${ }^{14} \mathrm{C}$ ages of water with low ${ }^{3} \mathrm{H}$ contents. The apparently shorter ${ }^{3} \mathrm{H}$ travel times of groundwater discharging at the group of interface springs with $>2$ TU may reflect: (1) limited bedrock underflow to the alluvial fan, (2) locally enhanced overland alluvial fan groundwater recharge, (3) infiltration along some alluvial fan stream channels, and (3) streamwater infiltration where the ephemeral streams cross permeable a)

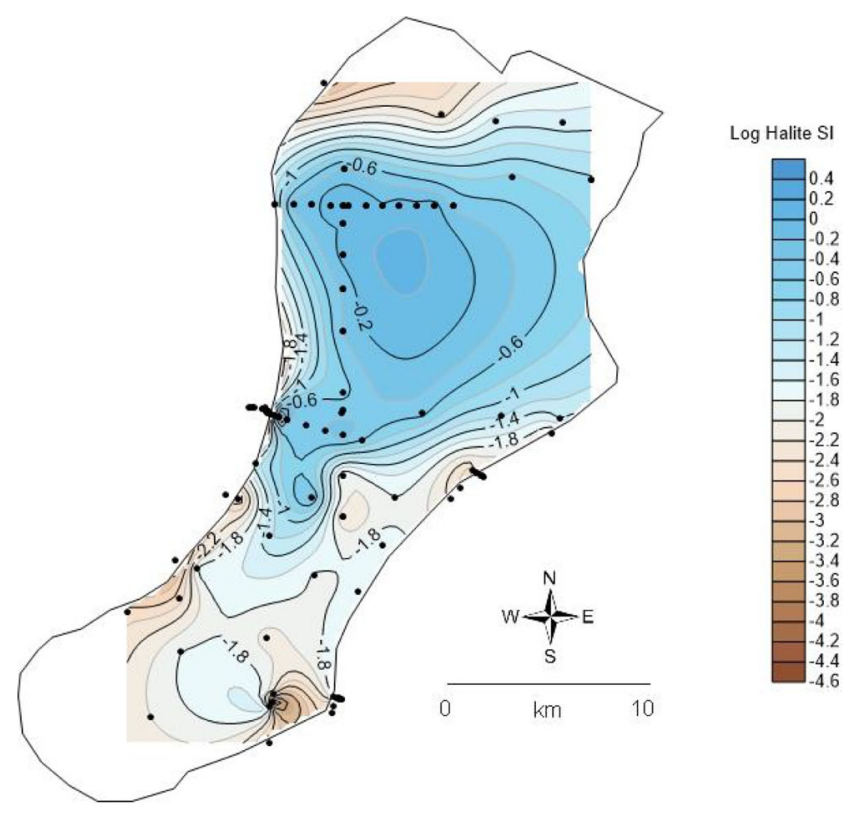

b)



Fig. 14 Contour maps of Lake Bonneville sediment groundwater a Halite saturation of groundwater in Lake Bonneville sediments, and b Gypsum saturation of groundwater in Lake Bonneville sediments. Saturation is $\log \mathrm{SI}=0.0 \pm 0.1$. Filled circles are sampling locations

shoreline sands near the alluvial fan-playa interface. Carling et al. (2012) and Mayo et al. (2020) found evidence for local alluvial fan streamwater infiltration, particularly where the channels cross shoreline sands near the fan-playa interface.

Pilot Range alluvial fan irrigation wells provide insight into the physical separation of the two types of alluvial fan groundwater systems. Five wells have been construction in the vicinity of Donner Spring (AS 10) at the alluvial fan-playa interface in the center subbasin. The wells, completed $18-30 \mathrm{~m}$ 

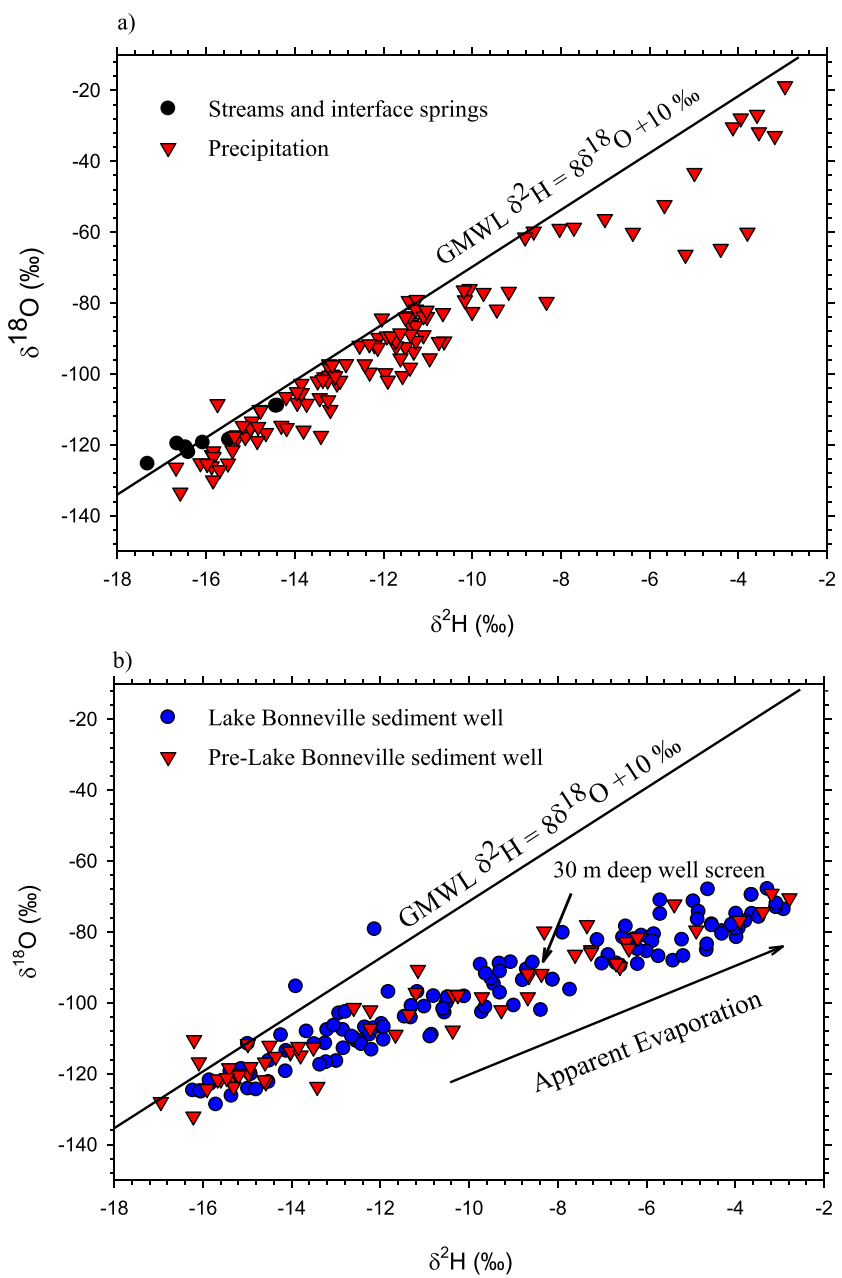

Fig. 15 Precipitation, surface and groundwater stable isotopic compositions plotted relative to the Global Meteoric Water Line (GMWL). a Precipitation, stream, and interface springs. b Basin wells

bgs, contain $\sim 7 \mathrm{TU}$ and $58 \mathrm{pmc}$. Some are seasonally pumped for intervals of 2-4 days and have drawdowns as great as $22 \mathrm{~m}$. The large drawdowns are consistent with a low hydraulic conductivity clayey matrix in the fan gravels. What is particularly significant is the fact that one of the well bores was dry to the 24.4-m bgs completion depth. The dry well bore and the clustering of the interface springs at the distal end of individual fans (Fig. 5) support the idea that the alluvial fan groundwater flow occurs in isolated systems. Isolated systems are consistent with the depositional history of the alluvial fans along the 23-km-long mountain front in that the mountain front alluvial fan system is a bajada (i.e., coalescing alluvial fans). Erosional fan debris carried by each of the major bedrock stream systems has its own internal depositional structure and distribution of coarse and fine-grained sediments. These internal sedimentary differences make it possible for some fans to more easily acquire modern recharge water than others.

South subbasin interface springs discharge from lake bed sediments and have elevated TDS (Table 3; Fig. 12). The a)


Fig. 16 Contours maps of groundwater $\delta^{18} \mathrm{O}$ contours in a Lake Bonneville sediment groundwater, and $\mathbf{b}$ pre-Lake Bonneville sediments groundwater. See Figs. 16, 17 and 18 for cross-section A-A'

upgradient bedrock and alluvial fan areas for both AS 9 and AS 12 are significantly undersized relative to the size of the groundwater recharge areas necessary to support the springs. During recent drought years these springs have only existed as ponds and do not discharge sufficient water to maintain their previously large wetland areas. The cause of the undersized upgradient recharge areas, particularly for AS 9, has 
a)



b)

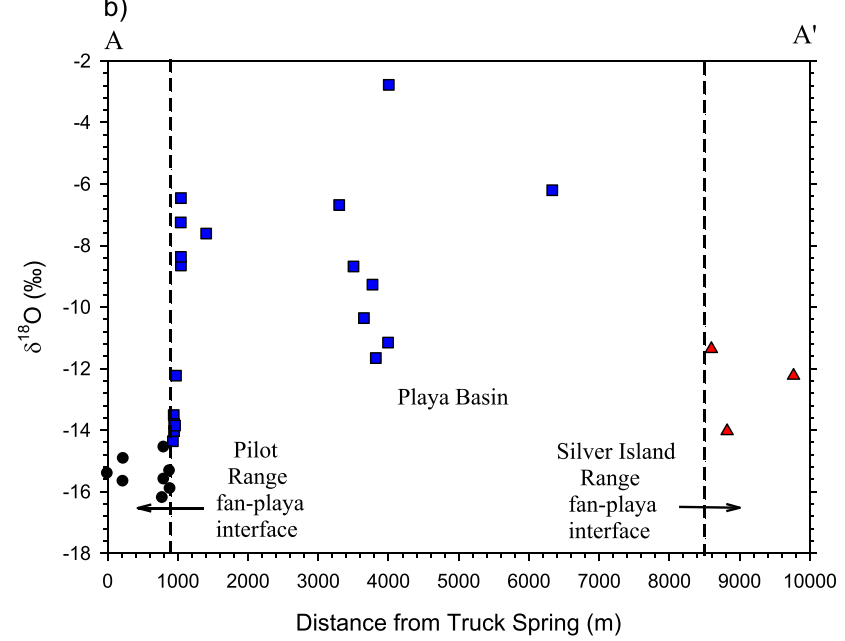

Fig. 17 Cross-section $\mathrm{A}-\mathrm{A}^{\prime}$ showing the $\delta^{18} \mathrm{O}$ compositions of: a Lake Bonneville and $\mathbf{b}$ pre-Lake Bonneville sediment groundwaters. All of the sampling locations are $>2 \mathrm{~m}$ bgs historically been problematic. The idea of south-moving horizontal groundwater flow from the Pilot Range bedrock massive along the damage zone of a Basin and Range frontal fault, followed by upwelling at the springs, is attractive; however, the ${ }^{3} \mathrm{H}$ contents of 1.9-4.0 TU of the spring waters preclude this idea. Such short apparent ${ }^{3} \mathrm{H}$ travel times of $\sim 12$ to 24 years and the absence of major ephemeral stream channels upgradient of the springs mean that the ${ }^{3} \mathrm{H}$ travel times are not consistent with the calculated ${ }^{14} \mathrm{C}$ ages and the long ${ }^{3} \mathrm{H}$ travel times associated with many of the north and center subbasin springs. It is more likely that the south subbasin springs AS 9 and AS 12 are supported by alluvial fan groundwater underflow from Pilot Creek valley located on the west side of the Pilot Range (Fig. 12). Here only a low elevation ridge of carbonate bedrock separates the Pilot Creek basin from the southwestern most Pilot Range alluvial fan. In the vicinity of AS 12, a distal reach of a Pilot Creek Valley anastomosing alluvial fan overlies the carbonate ridge. Likely alluvial fan groundwater flow paths are shown as arrows in Fig. 12.

\section{Basin groundwater}

Basin wide ${ }^{3} \mathrm{H}$ data indicate that the deeper pre-Lake Bonneville sediments contain older groundwater than the overlying Lake Bonneville sediments (Fig. 19a). The mean and median calculated ${ }^{3} \mathrm{H}$ ages of the deeper sediment groundwaters are $\sim 12$ and $24{ }^{3} \mathrm{H}$ years older than the overlying groundwater, respectively. The ${ }^{3} \mathrm{H}$ values for the two groundwater systems are statically different at the $95 \%$ confidence level with a $p$ value of 0.0085 . Near the alluvial fanplaya interface, Lake Bonneville sediment groundwater contains an average of $3.75 \mathrm{TU}$, whereas the deeper preLake Bonneville sediment groundwater only contains an
Fig. 18 Enlarged western portion of cross-section $\mathrm{A}-\mathrm{A}^{\prime}$ showing the abrupt change from nonevaporated to apparent evaporated groundwater at the boundary between the Pilot Range alluvia, the fan-playa interface, and the Pilot Valley playa. The transition from evaporative to apparently evaporated water occurs across about 100-m horizontal flow distance

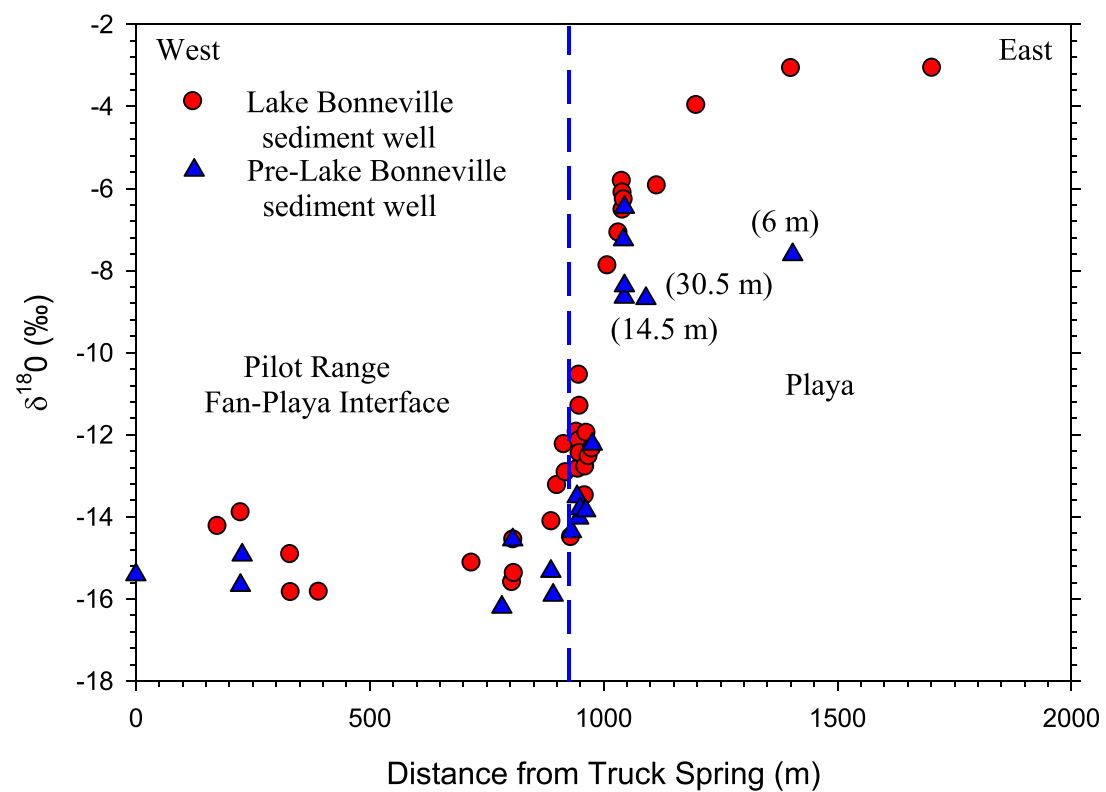


a)

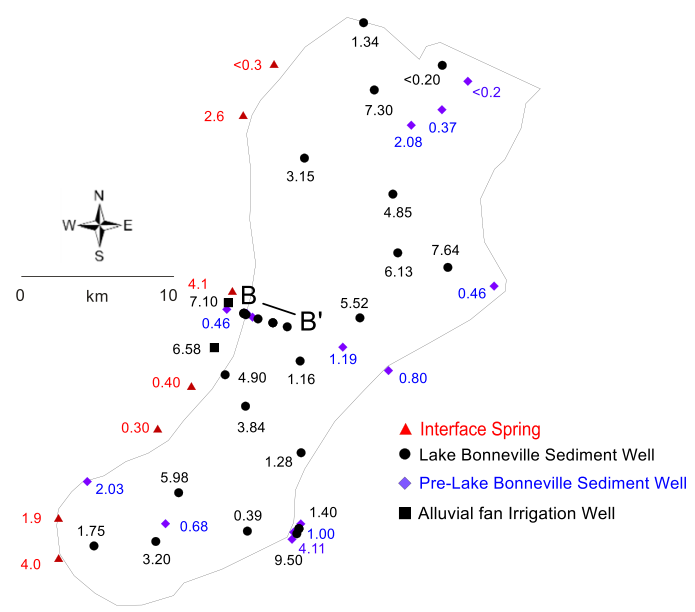

b)

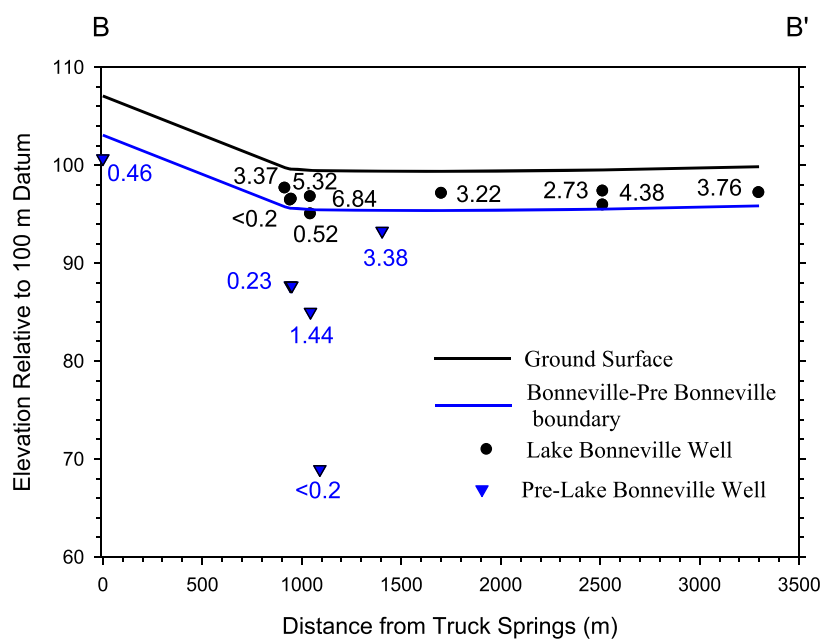

Fig. 19 The distribution of ${ }^{3} \mathrm{H}$ in: a all Pilot Valley groundwater and $\mathbf{b}$ groundwater at the Pilot Range alluvial fan-playa interface. All values are in tritium units (TU). The cross-section B- $\mathrm{B}^{\prime}$ is a shorten version of $\mathrm{A}-\mathrm{A}^{\prime}$ section shown in Figs. 6 and 16

average of 1.4 TU (Fig. 19b). This difference suggests that groundwater recharging the pre-Lake Bonneville sediments has about a 15 year longer ${ }^{3} \mathrm{H}$ travel time than the shallower groundwater. The $30 \mathrm{~m}$ deep well located near the interface contains $<0.2 \mathrm{TU}$ indicating more than 50 years of travel time for deepest groundwater flow. The longer ${ }^{3} \mathrm{H}$ travel times of the deeper groundwaters suggests that most shallow basin groundwater recharge occurs in the Lake Bonneville sediments and that upward contributions from deeper pre-Lake Bonneville sediment groundwater to the overlying sediments is limited.

The idea of shallow basin groundwater recharge from alluvial fan underflow is well established (Carling et al. 2012; Mayo et al. 2020). What is less well understood is the contribution of basin recharge from direct playa precipitation and playa flooding. Upward gradients from pre-Lake Bonneville to the Lake Bonneville sediments preclude pre-Lake
Bonneville sediment groundwater recharge from the playa surface. Although the areal distribution of apparently evaporated groundwater in center and north subbasin Lake Bonneville sediments is similar to areas that are occasionally or seasonally flooded (Fig. 16a), temporal water level data from nested wells in the topographic low of the north subbasin indicate that playa surface infiltration to the deeper portion of the Lake Bonneville sediments is not a factor (Fig. 20a). The data also show that there are continuous upward gradients throughout the stratigraphic column in the topographic low and that the pre-Lake Bonneville and Lake Bonneville sediment groundwater systems behave differently. In the north subbasin the shallowest Lake Bonneville sediment pressure surfaces are relatively stable throughout the water year, varying only about $0.2 \mathrm{~m}$ (Fig. 20b). In the deeper Lake Bonneville and pre-Lake Bonneville sediments water levels are seasonally dependent and vary more than $0.5 \mathrm{~m}$ in the pre-Lake Bonneville sediments. In the topographic low of the north subbasin the annual recharge pulse in the pre-Lake Bonneville sediments first arrives in May and continues to


Fig. 20 Temporal water level measurements in the north subbasin: a nested wells in the topographic low of the north subbasin, and $\mathbf{b}$ shallow wells in the Lake Bonneville sediments in the north subbasin. The values in the legend (a) are the depth to the top of the well screen 
build until late fall. What this means is that the flux of the annual recharge slug in the deep oolitic sand is greater than the rate of the permeability inhibited upward groundwater movement through the overlying clay sequences. The several month delay in the annual recharge pulse reaching the deeper Lake Bonneville sediments is consistent with slow vertical movement through the thick Lake Bonneville sediment clay package.

Evaporation is an attractive idea to be the cause of the apparent evaporative groundwater in the center and north subbasin Lake Bonneville sediments (Fig. 16a) as all the groundwater is ultimately lost to evaporation. However, less than $50 \%$ of the wells in the north subbasin are screened within $1 \mathrm{~m}$ of the ground surface (Fig. 21) and only five wells have top of well screens within $0.5 \mathrm{~m}$ of the ground surface. Basin wide only $17.5 \%$ of the wells have a top-of-well screen within $1 \mathrm{~m}$ of the ground surface. Additionally, the abrupt change from nonevaporated to apparent evaporated groundwater at the Pilot Range alluvial fan-playa interface occurs over a horizontal distance of about $100 \mathrm{~m}$ and at a depth of more than $2 \mathrm{~m}$ bgs (Fig. 18). What this means is that an alternative mechanism is responsible for most of the isotopic fractionation.

The pre-Lake Bonneville and Lake Bonneville sediment packages are fundamentally carbonate-clay membranes with thin stingers of water transmitting carbonate sand (Figs. 3 and 4). The clays, predominantly halloysite, Fe-smectite, illite, Fechlorite, and montmorillonite, surface charges and a cation exchange capacity (CEC) which allows them to interact with a range of solutes. It is well established that clay membranes can restrict the migration of solutes in native environments and in engineered barriers (Coplen and Hanshaw 1973; Fritz 1986; Malusis et al. 2012; Neuzil and Person 2017; Neuzil and Provost 2009; Whitworth and Fritz 1994). Laboratory experiments and field observations have demonstrated that hyperfiltration in clay environments, due to advective fractionation, can affect hydrogen, oxygen, carbon, chloride, and lithium isotopes (Benzel and Graf 1984; Campbell 1985; Coplen and Hanshaw 1973; Fritz et al. 1987; Hitchon and Friedman 1969; Oerter et al. 2014, 2018; Philips and Bentley 1987; Whitworth 1993; Wang et al., unpublished data). Although reported $\delta^{18} \mathrm{O}$ fractionation due to hyperfiltration has been only $1.5 \%$ or less, isotopic fractionation due to advective hyperfiltration is the likely process in Pilot Valley. The idea of hyperfiltration isotopic fractionation is supported by several factors: (1) evaporation is not a factor for most Pilot Valley fractionation, (2) sluggish flow through clay membranes induce hydrogen and oxygen isotopic fractionation, (3) the Pilot Valley sedimentary packages are thick clay membranes with strong upward gradients originating in thin water-bearing oolitic sand layers, (4) the very low permeability of the clay packages inhibits the upward groundwater flux, thus promoting the membrane effect, and (5) the evolution of $\delta^{18} \mathrm{O}$ from approximately
-16 to $<-10 \%$ occurs over extremely short horizontal flow distances and at depths of $2 \mathrm{~m}$ or more bgs.

\section{Groundwater chemical evolution}

The shallow-groundwater chemical evolution can be visualized as four geochemical flow paths: (1) infiltration of precipitation to the bedrock and alluvial fans, (2) alluvial fan flow to the alluvial fan-playa interface and interface springs, (3) interface flow to the basin sediments, and (4) basin margin and south to north subbasin flow (Fig. 22). Mountain bedrock and alluvial fan groundwater chemically evolves as it flows down gradient in response to soil zone $\mathrm{CO}_{2(\mathrm{~g})}$ and interactions with bedrock and alluvial fan minerals. At the alluvial fan-playa interface, water quality is impacted by contact with varying amounts of lake bed sediments that contain soluble sulfate and chloride minerals. Groundwater in the basin continues to evolve from fresh and brackish water at the alluvial fanplaya interface to saline, brine, and hypersaline $\mathrm{Na}-\mathrm{Cl}$ type water as it flows in basin sediments to the terminal sink in the salt pan area.

The first three flow paths are straight forward and behave as anticipated. The bedrock and alluvial fan groundwaters evolve from precipitation to low TDS $\mathrm{Ca}-\mathrm{HCO}_{3}$ and $\mathrm{Ca}-$ $\mathrm{Mg}-\mathrm{HCO}_{3}$ type groundwater in the aluminosilicate and carbonate terrains, respectively. The very low TDS of groundwater in the aluminosilicate terrain $(\sim 50 \mathrm{mg} / \mathrm{L})$ is due to the low solubility of the quarts, orthoclase, anorthite, and amphibole. The chemistry of carbonate terrain groundwater has a slightly higher TDS $(\sim 200 \mathrm{mg} / \mathrm{L})$ due to interactions with calcite and dolomite.

Although the north subbasin interface springs are down gradient of alumninosilicate alluvial fans and there are no surface outcrops of lake bed sediments, the increase in both $\mathrm{Na}^{+}$and $\mathrm{Cl}^{-}$, from 0.2 to 2.86 and 0.1 to $2.63 \mathrm{meq} / \mathrm{L}$, respectively, means that the groundwater flow paths encounter some lake bed sediments near the springs. Elsewhere, the progressive north to south increases in $\mathrm{Na}^{+}, \mathrm{Cl}^{-}$and $\mathrm{SO}_{4}{ }^{2-}$ in the interface spring waters (Fig. 12) are consistent with contact with increasing amounts of playa-lake bed carbonate mud that contains sulfate and chloride minerals. The chemical evolution of pre-Lake Bonneville and Lake Bonneville sediment groundwaters are similar despite the fact that the compositions of their initial waters vary and are location specific. The general pattern is to evolve from low to moderate TDS water at the alluvial fan-playa interface to saline and hypersaline $\mathrm{Na}-$ $\mathrm{Cl}$ type water with elevated $\mathrm{SO}_{4}{ }^{2-}$ as exemplified in groundwater density contour maps (Fig. 13).

Evaluating the chemical evolution of basin sediment groundwaters is more complex. The easy solution would be to attribute the evolution to contact with sulfate and chloride bearing minerals in the basin sediments and to significant evapoconcentration of Lake Bonneville sediment 
Fig. 21 Depth to the top of Lake Bonneville sediment well screens
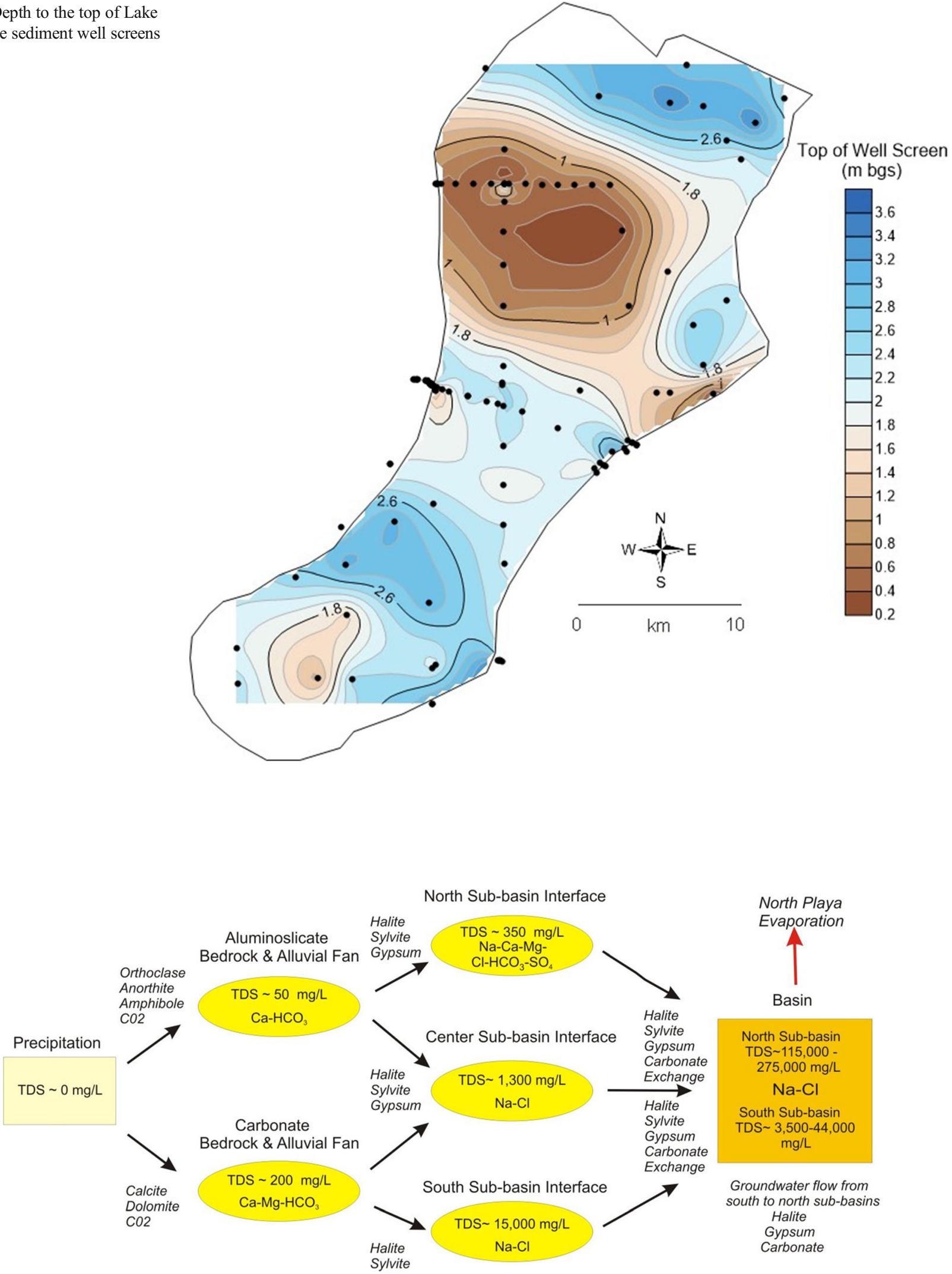

Fig. 22 Schematic diagram of Lake Bonneville sediments groundwater geochemical evolution. Primary mineral species controlling the chemical evolution for each step are shown in italics. The aluminosilicate bedrock and alluvial fan is restricted to the northern portion of the Pilot Range and

a small portion of the Leppy Hills. Carbonate bedrock and alluvial fan evolution describes both the southern Pilot Range and the Silver Island Range 
groundwater. Taken at face value the evaporative $\delta^{18} \mathrm{O}$ signatures of north and center subbasin pre-Lake Bonneville sediments (Figs. 15b and 16a) support this idea. As discussed above, the problem is that there are upward gradients between the two groundwater systems and only a small portion of the north subbasin well screens are within $1 \mathrm{~m}$ of the ground surface (Fig. 21). Evapoconcentration deeper than $1 \mathrm{~m}$ bgs is unlikely. Additionally, there is essentially no vertical chemical evolution in the conservative species $\mathrm{Cl}^{-}$and $\mathrm{SO}_{4}{ }^{2-}$ in nested wells in the north and center subbasin wells, although there is a substantial increase in $\mathrm{Cl}$ - from the center to north subbasin wells (Fig. 23). The decline in $\mathrm{SO}_{4}{ }^{2-}$ concentrations in the north subbasin nested wells relative to the south subbasin wells is attributed to gypsum precipitation in the supersaturated water (Fig. 14).

There could be an influx of evaporated groundwater from the Pilot Range alluvial fan due to the re-infiltration of evaporated spring discharge water at the alluvial fan-playa interface; however, such a mechanism is unlikely. The stable isotopic data at the alluvial fan-playa interface along the western edge of the center subbasin clearly demonstrates that the apparent evaporative signatures evolve in-situ and at depth (Fig. 18). The data also suggest that the apparent evaporative signatures in the center of the basin in both preLake Bonneville and Lake Bonneville sediments also evolve in-situ (Fig. 17). Although the most likely cause of the in-situ isotopic evolution is isotopic fractionation associated with hyperfiltration in the low hydraulic conductivity clays, hyperfiltration does not appear to impact the solute chemistry. The concentrations of the conservative species $\mathrm{Cl}^{-}$and $\mathrm{SO}_{4}{ }^{2-}$ are relatively stable or slightly increase in the vertical profiles of the nested wells (Fig. 23). The absence of a solute membrane effect is consistent with in-situ dissolution of the abundant sulfate and chloride minerals in the basin sediments (Fig. 4). The concentrations of sulfate and chloride minerals, which

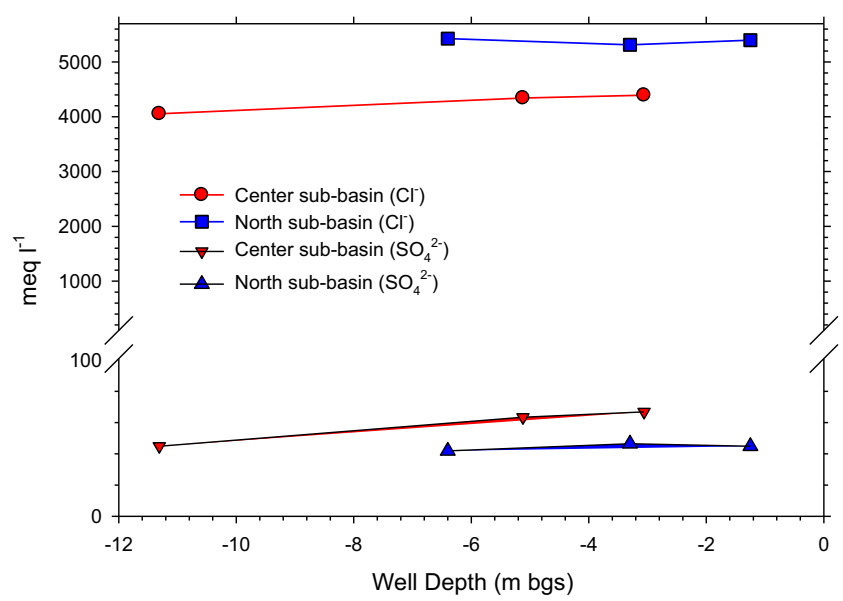

Fig. 23 TDS stratification in nested center and north subbasin pre-Lake Bonneville and Lake Bonneville sediment wells approach $10 \%$ by weight of the sediment mineralogy, means that there are ample soluble salts in the sediment package to account for the hypersalinity of the basin groundwaters.

\section{Geochemical modeling}

Inverse modeling was used because initial and final water compositions and flow-path mineralogy are known. Wellcharacterized mineral assemblages for both reactant and product phases are critical for inverse reaction modeling (Bowser and Jones 2002). Modeling each groundwater flow path was based on the average compositions of end member waters (Table 3) and mineral phases identified by RockJock analysis. Rayleigh distillation calculations for $\delta^{13} \mathrm{C}$ were used to better constrain the carbon evolution for the interface systems. $\delta^{13} \mathrm{C}$ was not used for basin sediment models as the carbon composition is substantially altered by interaction with carbonate mud. Because NETPATH-WIN does not validate results against SI, only modeling results which were consistent with the calculated SI of modeled mineral phases were considered plausible.

Representative groundwater flow paths selected for modeling were:

\section{Alluvial fan-playa interface:}

Flow path 1. Alumninosilicate alluvial fan to north subbasin alluvial fan-playa interface

Flow path 2. Carbonate alluvial fan to center subbasin alluvial fan-playa interface

Flow path 3. Carbonate alluvial fan to south subbasin alluvial fan-playa interface

\section{Basin sediment groundwater:}

Flow path 4.1 .0 to $1.01-1.05 \mathrm{~g} / \mathrm{cm}^{3}$

Flow path $5.1 .01-1.05$ to $1.05-1.1 \mathrm{~g} / \mathrm{cm}^{3}$

Flow path 6. $1.05-1.1$ to $1.11-1.15 \mathrm{~g} / \mathrm{cm}^{3}$

Flow path 7. $1.11-1.15$ to $1.15-1.21 \mathrm{~g} / \mathrm{cm}^{3}$

The chemistry at the interface springs was used to represent the interface chemistries. In NETPATH-WIN modeling, reactants and product phases are described in terms of constraints and phases. Constraints included the major elements $\mathrm{Ca}, \mathrm{Mg}$, $\mathrm{Na}, \mathrm{K}, \mathrm{C}, \mathrm{Cl}$, and $\mathrm{S}$, and $\delta^{13} \mathrm{C}$. Modeled phases were selected to be representative of the known mineralogy in the alluvial fans and basin sediments: (1) augite, K-feldspar, quartz, plagioclase (An35), and pyroxene for the dissolution of low solubility aluminosilicate minerals, and (2) calcite, dolomite, gypsum, halite, sylvite, and $\mathrm{Na}-\mathrm{Ca}$ ion exchange for alluvial fan-playa interface and basin minerals. Alluvial fan-playa interface models included $\delta^{13} \mathrm{C}$, and some basin models included evaporation. 
a)

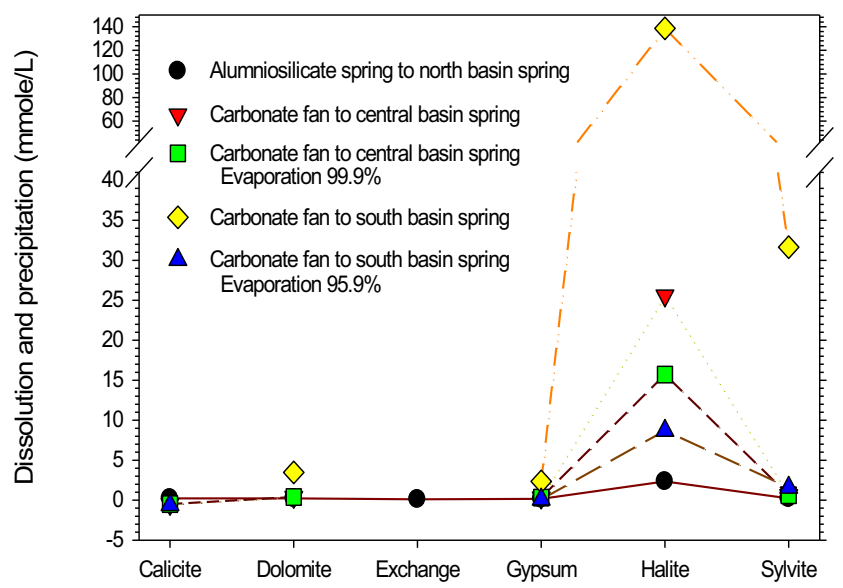

b)

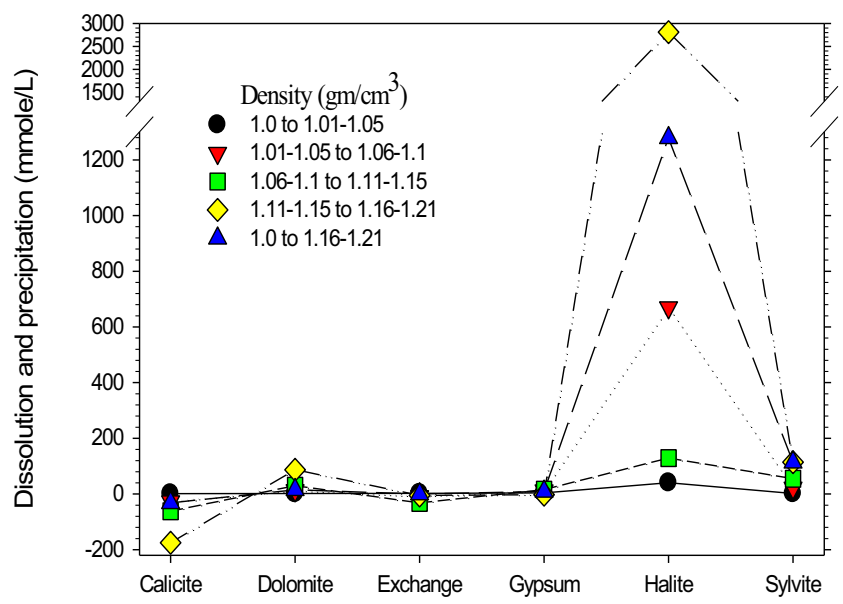

c)



Fig. 24 Representative NETPATH-WIN modeled phase changes associated with mineral dissolution and precipitation reactions. Negative values indicate precipitation and positive values indicate dissolution. Modeled reactions are for average concentrations organized by density: a alluvial fan to fan/playa interface models, b basin groundwater flow models without evaporation, and $\mathbf{c}$ basin groundwater flow models with evaporation. The percentages of water evaporated are listed $(\mathbf{a}, \mathbf{c})$
Alluvial fan to interface spring modeling results are consistent with the southerly increase in lake bed sediment content at the interface and indicate that evaporation could play a major role in the elevated chloride content (Fig. 24a). For example, in the south subbasin springs the modeled halite dissolution is 138.6 mmole $\mathrm{L}^{-1}$ without evaporation and is only $8.7 \mathrm{mmole}$ $\mathrm{L}^{-1}$ with $\sim 96 \%$ evaporation. A large evaporation contribution is unlikely because the sampled springs all flow freely. Except for the north subbasin springs, ion exchange was not a modeled result even though there is an abundance of clay minerals at the center and south subbasin fan-playa interfaces. Exchange was not a model outcome because the reacting equivalents of $\mathrm{Na}^{+}$and $\mathrm{Cl}^{-}$are similar in most waters (Table 3). Although basin sediments are not observed in the near surface geology associated with the north subbasin springs, the modeling indicates about $\sim 2 \mathrm{mmole}^{-1}$ of halite dissolution is required to account for the average $93 \mathrm{mg} / \mathrm{L} \mathrm{Cl}^{-}$ concentration.

Basin sediment models included both no evaporation and evaporation (Fig. 24b,c). Evaporation is only plausible in the topographic low of the north subbasin. Calcite precipitation is common in most model runs, which helps explain the carbonate mineral content of the basin sediments (Fig. 4). Not surprisingly, the modeling demonstrates that halite is the primary driver of elevated TDS with or without evaporation. Evaporation is likely a significant factor in the north subbasin areas where groundwater is near the land surface, but not elsewhere.

\section{Salt transfer}

The modeling demonstrates that pervasive sulfate and chloride mineral dissolution plus evaporation in the near surface sediments in the topographic low of the north subbasin are the driving mechanisms in basin groundwater evolution. However, the modeling does not answer the key questions: (1) why does the TDS and mineral saturation progressively increase along the flow path (Fig. 13), and (2) what is the origin of the salt pan? Two possible mechanisms could account for the progressive increase in TDS and mineral saturation. The sulfate and chloride mineral content of the sediments may progressively increase from the south to the north and from the basin margins. Alternatively, the groundwater flow may progressively wash out soluble minerals up gradient and transfer the salts to the topographic and structural low of the basin. The limited data suggest that halite and gypsum concentrations in Lake Bonneville sediments are relatively constant in the south and center subbasins at about $0.01-0.04$ and $0.004-0.009 \mathrm{~g} / \mathrm{cm}^{3}$ for gypsum and halite, respectively. Gypsum increases to $0.028 \mathrm{~g} /$ $\mathrm{cm}^{3}$ in the most northern portion of the north subbasin and halite locally increases to $0.18 \mathrm{~g} / \mathrm{cm}^{3}$ in the center of the north subbasin. The fact that areas in both the north and center subbasins with elevated gypsum and halite saturation do not 




Fig. 25 Conceptual model of Pilot Valley endorheic basin shallowgroundwater hypersalinization and salt pan formation. Groundwater flow is horizontal toward the topographic low of the basin (black arrows). When the water table is within $1 \mathrm{~m}$ of the ground surface, capillary flow

(red arrows) and surface evaporation begins. Surface deposited salts are redissolved and flushed to the salt pan during the flooding season, and redeposited during the dry season. Not to scale

correspond with the regions of elevated sediment mineral concentrations suggests that the distribution of gypsum and halite is not the primary driver of the progressive increase in TDS.

The concentrations of gypsum and halite throughout the basin sediments suggests that continuous mineral dissolution occurs along the groundwater flow paths until mineral saturation is reached (Fig. 25). The most likely source of these minerals was co-precipitation with fine-grained detrital deposition associated with Lake Bonneville and earlier lakes in the nearly closed Pilot Valley embayment. Evaporation from the playa surface is a contributing factor in the increased gypsum and halite saturation in Lake Bonneville sediments where the water surface is within $1 \mathrm{~m}$ of ground surface. As the water moves to the surface via capillary action it carries the dissolved soluble salts to the land surface where they precipitate. Episodic flooding then redissolves the salt and carries it to the annually flooded salt pan where it accumulates and forms a salt crust during the dry season.

\section{Conclusions}

Pilot Valley shallow groundwater chemical evolution can be visualized along four geochemical flow paths: (1) infiltration of precipitation to the bedrock and alluvial fans, (2) alluvial fan flow to the alluvial fan-playa interface, (3) interface flow to the endorheic basin sediments, and (4) basin margin and south to north subbasin flow. Of interest here is the upper most $12 \mathrm{~m}$ of the basin sediment consisting of low hydraulic conductivity Pleistocene age Lake Bonneville and pre-Lake Bonneville lacustrine calcareous mud with a few oolitic sand units. The oolitic sands transmit most shallow-basin active groundwater flow and the clay sequences are effectively thick clay membranes. The oolitic sands are not near the top of the sedimentary sequence and the flux of vertical flow is inhibited by the thick lacustrine clay.

Shallow groundwater in much of the central and northern portion of the basin has apparent evaporative $\delta^{2} \mathrm{H}$ and $\delta^{18} \mathrm{O}$ signatures. Isotopic fractionation of up to $-8 \%$ in $\delta^{18} \mathrm{O}$ is attributed to hyperfiltration in the clay sequences. Groundwater in the basin evolves from fresh and brackish water at the alluvial fan-playa interface to saline, brine, and hypersaline $\mathrm{Na}-\mathrm{Cl}$ type water as it flows to the terminal sink in the salt pan area. Although hyperfiltration impacts the stable isotopes, hyperfiltration has not significantly affected most of the basin groundwater chemistry. The absence of a significant solute membrane effect is the result of the abundance of sulfate and chloride minerals in the basin sediments.

Based on an analysis of sediment mineralogy, water levels, and solute and isotopic compositions a model of shallow endorheic basin groundwater chemical evolution and hypersalinization that does not involve basin wide evaporation has been developed. The model envisions the remobilization of authigenic soluble salts that were deposited over time with fine-grained detrital sediments in the endorheic basin. Groundwater flow path sulfate and chloride mineral dissolution is the primary driving mechanism for hypersalinization. Evaporation only impacts the groundwater quality where the groundwater is within $\sim 1 \mathrm{~m}$ of the ground surface. Here capillary action carries dissolved soluble salts to the land surface. Episodic flooding redissolves and carries the precipitated salt to the annually flooded salt pan where it accumulates as a salt crust during the dry season.

The Pilot Valley model may help explain the long-term accumulation of buried layers containing local concentrations of highly soluble ions in some endorheic basins. When these concentrated zones include high porosity layers, brines may be commercially extracted.

Supplementary Information The online version contains supplementary material available at https://doi.org/10.1007/s10040-021-02371-7.

Acknowledgements We are indebted to the hundreds of BYU students who constructed wells, collected samples, operated geophysical equipment, and performed other tasks as their Pilot Valley field camp assignments. We thank Tamera Bills, Tamalynn Pulsipher, and Mark Nichols 
who assisted us in both the field and laboratory. We also thank the three anonymous reviewers whose insights help us clarify and broaden the appeal of the manuscript.

\section{Declarations}

Conflict of interest On behalf of all authors, the corresponding author states that there is no conflict of interest.

Open Access This article is licensed under a Creative Commons Attribution 4.0 International License, which permits use, sharing, adaptation, distribution and reproduction in any medium or format, as long as you give appropriate credit to the original author(s) and the source, provide a link to the Creative Commons licence, and indicate if changes were made. The images or other third party material in this article are included in the article's Creative Commons licence, unless indicated otherwise in a credit line to the material. If material is not included in the article's Creative Commons licence and your intended use is not permitted by statutory regulation or exceeds the permitted use, you will need to obtain permission directly from the copyright holder. To view a copy of this licence, visit http://creativecommons.org/licenses/by/4.0/.

\section{References}

Anderson WL (1957) Geology of the northern Silver Island Mountains, Box Elder and Tooele counties, Salt Lake City, Utah. MSc Thesis, University of Utah, Salt Lake City, UT, 313 pp

Anderson WL (1960) Geologic map of the northern Silver Island Mountains, Box Elder and Tooele Counties, Utah. In: Geology of the Silver Island Mountains, Box Elder and Tooele counties, Utah and Elko County, Nevada. Guidebook to the Geology of Utah, no. 15, pl. 2a, Utah Geological Association, Salt Lake City, UT

Bayari CS, Ozyut NN, Kilani S (2008) Radiocarbon age distribution of groundwater in the Konya Closed Basin, central Anatolia, Turkey. Hydrogeol J 17:347-365. https://doi.org/10.1007/s10040-0080358-2

Benzel WM, Graf DL (1984) Studies of smectite membrane behavior: importance of layer thickness and fabric in experiments at $20^{\circ} \mathrm{C}$. Geochim Cosmochim Acta 48(9):1769-1778. https://doi.org/10. 1016/0016-7037(84)90031-0

Bowser CJ, Jones BF (2002) Mineralogical controls on the composition of natural waters dominated by silicate hydrolysis. Am J Sci 302(7): 582-662. https://doi.org/10.2475/ajs.302.7.582

Carling GT, Mayo AL, Tingey D, Bruthans J (2012) Mechanisms, timing, and rates of arid region mountain front recharge. J Hydrol 428-429:51-31. https://doi.org/10.1016/j.jhydrol.2011.12.043

Cartwright I, Hannam K, Weaver TR (2007) Constraining flow paths of saline groundwater at basin margins using hydrochemistry and environmental isotopes: Lake Cooper, Murray Basin, Australia. Aust J Earth Sci 54(8):1103-1122. https://doi.org/10.1080/ 08120090701615741

Campbell DJ (1985) Fractionation of stable chlorine isotopes during transport through semipermeable membranes. MSc Thesis, Univ. of Arizona, Tuscon, AZ, 103 pp

Coplen TB, Hanshaw BB (1973) Ultrafiltration by a compacted clay membrane: I. oxygen and hydrogen isotopic fractionation. Geochim Cosmochim Acta 37:2295-2310. https://doi.org/10. 1016/0016-7037(73)90106-3

Cook KL, Halverson MD, Stepp JC, Bert JW Jr (1964) Regional gravity survey of the northern Great Salt Lake Desert and adjacent areas in Utah, Nevada, and Idaho. Geol Soc Am Bull 75(8):715-740. https:// doi.org/10.1130/0016-7606(1964)75[715:RGSOTN]2.0.CO;2
Duffy CJ, Al-Hassan S (1988) Groundwater circulation in a closed desert basin: topographic scaling and climatic forcing. Water Res Res 24(10):1675-1688. https://doi.org/10.1029/WR024i010p01675

Eberl DD (2003) User's guide to RockJock: a program for determining quantitative mineral from powder x-ray diffraction data. US Geol Surv Open-File Rep 2003-78, 47 pp

Edmunds WM, Aeschbach-Hertig J, Ma W, Kipfer R, DPF D (2006) Groundwater recharge history and hydrogeochemical evolution in the Minqin Basin, North West China. Appl Geochem 21:21482170. https://doi.org/10.1016/j.apgeochem.2006.07.016

El-Kadi AI, Plummer LN, Aggarwal P (2011) NETPATH-WIN: an interactive user version of the mass-balance model. Ground Water 49(4):593-599. https://doi.org/10.1111/j.1745-6584.2010.00779

Eugster HP (1980) Geochemistry of evaporitic lacustrine deposits. Annu Rev Earth Planet Sci 8:35-63

Fan Y, Duffy J, Oliver DS (1997) Density-driven groundwater flow in closed desert basins: field investigations and numerical experiments. J Hydrol 196(1-4):139-184. https://doi.org/10.1016/S00221694(96)03292-1

Fritz SJ (1986) Ideality of clay membranes in osmotic processes: a review. Clays Clay Mins 34(2):214-223. https://doi.org/10.1346/ CCMN.1986.0340212

Fritz SJ, Hinz DW, Grossman EL (1987) Hyperfiltration-induced fractionation of carbon isotopes. Geochim Cosmochim Acta 5:1112111134. https://doi.org/10.1016/0016-7037(87)90205-5

Gilbert GK (1890) Lake Bonneville. US Geol Surv Monolith 1, 438 pp

He J, Ma J, Zhao W, Sun S (2015) Groundwater evolution and recharge determination of the Quaternary aquifer in the Shule River basin, Northwest China. Hydrogeol J 23:1745-1759. https://doi.org/10. 1007/s10040-015-1311-9

Hamann E, Post V, Kohfahl C, Prommer H, Simmons CT (2015) Numerical investigation of coupled density-driven flow and hydrogeochemical processes below playas. Water Resour Res 51:93389352

Hardie LA (1991) On the significance of evaporites. Annu Rev Earth Planet Sci 19:131-168

Harrill JR (1971) Water-resources appraisal of the Pilot Creek Valley area, Elko and White Pine counties. Nevada Department of Conservation and Natural Resources Water Resources Reconnaissance Report 56, Nevada Department of Conservation, Carson City, NV, 46 pp

Herrera C, Custodio E, Chong G, Lambán LJ, Riquelme R, Wilke H, Jódar J, Urrutia J, Urqueta H, Sarmiento A, Gam-boa C, Lictevout E (2016) Groundwater flow in a closed basin with a saline shallow lake in a volcanic area: Laguna Tuyajto, northern Chilean Altiplano of the Andes. Sci Total Environ 541:303-318. https://doi.org/10. 1016/j.scitotenv.2015.09.060

Hitchon B, Friedman I (1969) Geochemistry and origin of formation waters in the western Canada sedimentary basin: I. stable isotopes of hydrogen and oxygen. Geochim Cosmochim Acta 33(11):3211349. https://doi.org/10.1016/0016-7037(69)90178-1

Johnson E, Yáñez J, Ortiz C, Muñoz J (2010) Evaporation from shallow groundwater in closed basins in the Chilean Altiplano. Hydrogeolog Sci J 559(4):624-635. https://doi.org/10.1080/02626661003780458

Lines GC (1979) Hydrology and surface morphology of the Bonneville Salt Flats and Pilot Valley. US Geol Surv Water Suppl Pap 2057, $107 \mathrm{pp}$

Love AJ, Shand P, Fulton S, Wohling D, Karlstrom KE, Crossey L, Rousseau-Gueutin P, Priestley SC (2017) A reappraisal of the hydrogeology of the western margin of the Great Artesian Basin: chemistry, isotopes and groundwater flow. Procedia Earth Plan Sci 17:428-431. https://doi.org/10.1016/j.proeps.2016.12.108

Lowenstein TK, Risacher F (2009) Closed basin brine evolution and the influence of $\mathrm{Ca}-\mathrm{Cl}$ inflow waters: Death Valley and Bristol Dry Lake California, Qaidam Basin, China, and Salar de Atacama, 
Chile. Aquat Geochem 15:71-94. https://doi.org/10.1007/s10498008-9046-z

Liutkus CM, Wright JD (2008) The influence of hydrology and climate on the isotope geochemistry of plays carbonates: a study from Pilot Valley, NV, USA. Sedimentology 55:965-978. https://doi.org/10. 1111/j.1365-3091.2007.00932.x

Malusis MA, Shackelford CD, Maneval JE (2012) Critical review of coupled flux formulations for clay membranes based on nonequilibrium thermodynamics. J Contaminant Hydrol 138-139:40-59. https://doi.org/10.1016/j.jconhyd.2012.06.003

Marazuela MA, Vázquez-Suñé E, Ayora C, García-Gil A (2020) Towards more sustainable brine extraction in salt flats: Learning from the Salar de Atacama. Sci Total Environ 703:135606. https:// doi.org/10.1016/j.scitotenv.2019.135605

Mason JL, Brother WC, Gerner LJ, Muir PS (1995) Selected hydrologic data for the Bonneville Salt Flats and Pilot Valley, western Utah, 1991-1993. US Geol Surv Open-File Rep 95-104, 56 pp

Massuel S, Favreau G, Descloitres ML, Troquer Y, Albouy Y, Cappelaere B (2006) Deep infiltration through a sandy alluvial fan in semiarid Niger inferred from electrical conductivity survey, vadose zone chemistry and hydrological modeling. Catena 67(2):105118. https://doi.org/10.1016/j.catena.2006.02.009

Mayo AL, Davey A, Christiansen D (2007) Groundwater flow patterns in the San Luis Valley, Colorado, USA, revisited: an evaluation of solute and isotopic data. Hydrogeol J 15(2):383-408. https://doi. org/10.1007/s10040-006-0079-3

Mayo AL, Tingey DG (2021) Continental interior storm tracks, tritium deposition, and precipitation isotopes at the Great Basin-Rocky Mountain physiographic provinces transition zone, USA. Earth Space Sci Open Archive. https://doi.org/10.1002/essoar.10506861.

Mayo AL, Hendrson RM, Tingey D, Webber W (2010) Chemical evolution of shallow playa groundwater in response to post-pluvial isotactic rebound, Honey Lake Basin, California-Nevada, USA. Hydrogeol J 18(3):725-747. https://doi.org/10.1007/s10040-0090542-z

Mayo AL, Tingey DG, Rey KT, Winkel AD, McBride J, Nelson ST, Carling GT, Bruthans J, Peterson EC (2020) Shallow groundwater flow and inverted fresh/saline water interface in a hypersaline endorheic basin: Great Basin, USA. Hydrogeol J 28:2877-2902. https://doi.org/10.1007/s10040-020-02209-8

Meybeck M, Green P, Vörösmarty C (2001) A new typology for mountains and other relief classes: an application to global continental water resources and population distribution. Mountain Res Development 21(1):34-45. https://doi.org/10.1659/02764741(2001)021[0034:ANTFMA]2.0.CO;2

Miller DM (1984) Sedimentary and igneous rocks of the pilot range and vicinity, Utah and Nevada in geology of northwestern Utah and southern Idaho and Northeast Nevada. Utah Geol Assoc Field Conf 13:45-63

Miller DA (1985) Geologic map of the Lucin Quadrangle, Box Elder County, Utah. Utah Geological Survey Map 78, Utah Geological Survey, Salt Lake City, UT, 2 plates, 10 pp

Miller DA (1990a) Geologic map of the Crater Island SW Quadrangle, Box Elder County, Utah. Utah Geological Survey Map 129, Utah Geological Survey, Salt Lake City, UT, 2 plates, 8 pp

Miller DA (1990b) Geologic map of the Lucin 4 NW Quadrangle, Box Elder County. Utah Geological Survey Map 130, Utah Geological Survey, Salt Lake City, UT, 2 plates, 13 pp

Miller DM (1993) Geologic map of the Crater Island NW Quadrangle, Box Elder County, Utah. Utah Geological Survey Map 145, Utah Geological Survey, Salt Lake City, UT, 2 plates, 13 pp

Miller DM, Lush AP (1994) Geologic map of the Pilot Peak Quadrangle, Box Elder County, Utah, and Elko County, Nevada. Utah Geological Survey Map 160, Utah Geological Survey, Salt Lake City, UT, 2 plates, 25 pp
Miller DM, Phelps GA (2016) The Pilot Valley shoreline: an early record of Lake Bonneville dynamics. In: Oviatt CG, Shroder JF Jr (eds) Lake Bonneville a scientific update. Develop Earth Surf Processes 20(3):60-74. https://doi.org/10.1016/B978-0-444-63590-7.00003-2

Miller DM, Jordan TE, Allmendinger RW (1990) Geologic map of the Crater Island Quadrangle, Box Elder County, Utah. Utah Geological Survey Map 128, Utah Geological Survey, Salt Lake City, UT, 2 plates, $16 \mathrm{pp}$

Miller DM, Lush AP, Schneyer JD (1993) Geologic map of the Patterson Pass, Box Elder County, Utah and Elko County, Nevada. Utah Geological Survey Map 144, Utah Geological Survey, Salt Lake City, UT, 2 plates, 20 pp

Neuzil CE, Person M (2017) Reexamining ultrafiltration and solute transport in groundwater. Water Resour Res 63(6):4922-4941. https:// doi.org/10.1002/2017WR020492

Neuzil CE, Provost AM (2009) Recent experimental data may point to a greater role for osmotic pressures in the subsurface. Water Res Res 45(3):1-14. https://doi.org/10.1029/2007WR006450

Nolan TB (1928) Potash brines in the great Sale Lake Desert, Utah. In: Loughlin GF, Mansfield GR (eds) Contributions to economic geology, part 1: metals and nonmetals except fuels. US Geol Surv Bull 795:24-44

Oerter E, Finstad K, Schaefer J, Goldsmith GR, Dawson T, Amundson R (2014) Oxygen isotope fractionation effects in soil water via interactions with cations $(\mathrm{Mg}, \mathrm{Ca}, \mathrm{K}, \mathrm{Na})$ adsorbed to phyllosilicate clay minerals. J Hydrol 515(16):1-9. https://doi.org/10.1016/j.jhydrol. 2014.04.029

Oerter EJ, Singleton M, Davisson ML (2018) Hydrogen and oxygen stable isotope dynamics of hyper-saline and salt-saturated aqueous solutions. Geochim Cosmochim Acta 238:316-328. https://doi.org/ 10.1016/J.GCA.2018.07.009

Oliver DS Jr (1992) An experimental study of groundwater flow and salinity dynamics of a playa margin. MSc Thesis, Utah State University, Salt Lake City, UT, 130 pp

O'Neil JM (1968) Geology of the southern Pilot Range, Elko County, Nevada and Box Elder County, Utah. MSc Thesis, University of New Mexico, Albuquerque, NM, 112 pp

Ortega GA (2003) Origin and geochemical evolution of groundwater in a closed-basin clayey aquitard, northern Mexico. J Hydrol 284(1-4): 26-44. https://doi.org/10.1016/S0022-1694(03)00239-7

Peterson EC (1993) Geochemical evolution of groundwater with implications for groundwater flow patterns in the Pilot Valley closed basin, Utah and Nevada. MSc Thesis, Brigham Young University, Provo, UT, $124 \mathrm{pp}$

Phillips FM, Bentley HW (1987) Isotopic fractionation during ion filtration: I. theory. Geochim Cosmochim Acta 51:683-695. https://doi. org/10.1016/0016-7037(87)90079-2

Post V, Cook PG, Banks E (2014) Multi-tracer characterization of saline groundwater bodies in coastal area and implications for paleo-hydrology. American Geophsyical Union Fall Meeting, abstract H23D-0911, AGU, Washington, DC

Priestley SC, Love AJ, Post V, Shand P, Wohling D, Kipfer R, Payne TE, Stute M, Tyroller L (2017) Environmental tracers in groundwaters and pore waters to understand groundwater movement through an argillaceous aquitard. Procedia Earth Plan Sci 17:20-423. https:// doi.org/10.1016/j.proeps.2016.12.106

Rey KA, Mayo AL, Tingey DG, Nelson ST (2016) Late Pleistocene to early Holocene sedimentary history of the Lake Bonneville Pilot Valley embayment, Utah-Nevada, USA. In: Oviatt CG, Shroder JF Jr (eds) Lake Bonneville a scientific update. Develop Earth Surf Processes 20(3):184-220. https://doi.org/10.1016/B978-0-44463590-7.00010-X

Risacher F, Fritz B (2009) Origin of salts and brine evolution of Bolivian and 1125Chilean salars. Aquat Geochem 15(1-2):123-157 
Rissmann C, Leybourne M, Benn C, Christenson B (2015) The origin of solutes within the groundwaters of a high Andean aquifer. Chem Geol 396:164-181

Rosen MR (1994) The importance of groundwater in playas: a review of playa classifications and the sedimentology and hydrology of playas. Geol Soc Am Spec Pap 289:1-18

Sabarathinam C, Bhandary H, Khalid A (2018) Tracing the evolution of hypersaline coastal groundwater in Kuwait: an integrated approach. In: Chamine HI, Barbieri M, Kisi O, Chen M, Merkel BJ (ed) Advances in sustainable and environmental hydrology, hydrogeology, hydrochemistry and water resources. CAJG 2018, Advances in Science, Technology and Innovation (IEREK Interdisciplinary Series for Sustainable Development). Springer, Cham, Switzerland, pp 185-188. https://doi.org/10.1007/978-3-03001572-5 45

Scanlon BR, Stonestrom DA, Reedy RC, Leaney FW, Gates J, Cresswell RG (2009) Inventories and mobilization of unsaturated zone sulfate, fluoride, and chloride related to land use change in semiarid regions, southwestern United States and Australia. Water Res Res 45(7):117. https://doi.org/10.1029/2008WR006963

Schaeffer FE, Anderson WL (1960) Geology of the Silver Island Mountains, Box Elder and Tooele counties, Utah and Elko County Nevada. Utah Geological Society Guidebook 15, Utah Geological Society, Salt Lake City, UT, 192 pp

Shand P, Love AJ, Gotch T, Raven MD, Kirby J, Scheiderich K (2013) Extreme acidic environments associated with carbonate mound springs in the Great Artesian Basin South Australia. Procedia Earth Plan Sci 7:794-797. https://doi.org/10.1016/j.proeps.2013. 03.055

Shuya HU, Zhao Q, Wang G, Zhang J, Feng J (2018) Hydrochemical dynamic characteristics and evolution of underground brine in the Mahai Salt Lake of the Qaidam Basin Qinghai-Tibet plateau. Acta Geol Sin 92(5):1981-1990. https://doi.org/10.1111/1755-6724. 13690

Stansbury H (1852) Exploration and survey of the valley of the great salt Lake of Utah including a reconnaissance of a new route through the Rocky Mountains. US Senate, special session March 1851, Lippincott, Philadelphia, PA, 487 pp

Stephens JC, Hood JW (1973) Hydrologic reconnaissance of Pilot Valley, Utah and Nevada. Technical Publ. 41, Utah Department of Natural Resources, Salt Lake City, UT, 38 pp
South JV, McBride JH, Carling GT, Mayo AL, Tingey DG, Rey KA, Nelson ST (2016) Imaging the margins of Pleistocene lake deposits with high-resolution seismic reflection in the Eastern Basin and Range: Pilot Valley Utah (USA) In: Oviatt CG, Shroder JF Jr (eds) Lake Bonneville a scientific update. Develop Earth Surf Processes 20(3):526-550. https://doi.org/10.1016/B978-0-44463590-7.00003-2

Tweed S, Leblanc M, Cartwright I, Favreau G, Leduc C (2011) Arid zone groundwater recharge and salinization processes; an example from the Lake Eyre Basin, Australia. J Hydrol 408(3-4):257-275. https:// doi.org/10.1016/j.jhydrol.2011.08.008

UNESCO (2014) Hydrology (IHP). www.unesco.org/water/ihp/ publications/waterway/webpc/pag13.html. Accessed November 4, 2014

Van Engelen J, Oude E, Gualbert HP, Kooi H, Bierkens MFP (2017) On the origins of hypersaline groundwater in the Nile Delta aquifer. $\mathrm{J}$ Hydrol 500:301-317. https://doi.org/10.1016/j.jhydrol.2018.03.029

Whitworth TM (1993) Hyperfiltration-induced isotopic fractionation: mechanisms and role in the subsurface. PhD Thesis, Purdue University, West Lafayette, IN

Whitworth TM, Fritz SJ (1994) Electrolyte-induced solute permeability effects in compacted smectite membranes. Appl Geochem 9(5): 533-546. https://doi.org/10.1016/0883-2927(94)90015-9

Winkel AD (2007) Inverted freshwater/brine aquifer interface and osmotic pressure ridge, Pilot Valley, Utah. MS Thesis, Brigham Young University, Provo, UT, $92 \mathrm{pp}$

Xiao Y, Shao J, Cui Y, Zhang G, Zhang Q (2017) Groundwater circulation and hydrogeochemical evolution in Nomhon of Qaidam Basin, Northwest China. J Earth Syst Sci 126:1-15. https://doi.org/10. 1007/s12040-017-0800-8

Xiao Y, Shao J, Frape SK, Cui Y, Dang X, Wang S, Ji Y (2018) Groundwater origin, flow regime and geochemical evolution in arid endorheic watersheds: a case study from the Qaidam Basin, northwestern China. Hydrol Earth Syst Sci 22:4381-4400. https://doi. org/10.5194/hess-22-4381-2018

Publisher's note Springer Nature remains neutral with regard to jurisdictional claims in published maps and institutional affiliations. 